\title{
Reviews and syntheses: The mechanisms underlying carbon storage in soil
}

\author{
Isabelle Basile-Doelsch $^{1}$, Jérôme Balesdent ${ }^{1}, \boldsymbol{t}$, and Sylvain Pellerin ${ }^{2}$ \\ ${ }^{1}$ Aix-Marseille University, CNRS, IRD, INRAE, Coll France, CEREGE, Aix-en-Provence, France \\ ${ }^{2}$ INRAE, Bordeaux Sciences Agro, University of Bordeaux, 33882, Villenave d'Ornon, France \\ $\boldsymbol{t}_{\text {deceased, } 19 \text { July } 2020}$
}

Correspondence: Isabelle Basile-Doelsch (basile@ cerege.fr)

Received: 11 February 2020 - Discussion started: 19 February 2020

Revised: 26 August 2020 - Accepted: 3 September 2020 - Published: 30 October 2020

\begin{abstract}
Soil organic matter (OM) represents a key C pool for climate regulation but also an essential component for soil functions and services. Scientific research in the 21st century has considerably improved our knowledge of soil organic matter and its dynamics, particularly under the pressure of the global disruption of the carbon cycle. This paper reviews the processes that control $\mathrm{C}$ dynamics in soil, the representation of these processes over time, and their dependence on variations in major biotic and abiotic factors. The most recent advanced knowledge gained on soil organic matter includes the following. (1) Most organic matter is composed of small molecules, derived from living organisms, without transformation via additional abiotic organic polymerization; (2) microbial compounds are predominant in the long term; (3) primary belowground production contributes more to organic matter than aboveground inputs; (4) the contribution of less biodegradable compounds to soil organic matter is low in the long term; (5) two major factors determine the soil organic carbon production "yield" from the initial substrates: the yield of carbon used by microorganisms and the association with minerals, particularly poorly crystalline minerals, which stabilize microbial compounds; (6) interactions between plants and microorganisms also regulate the carbon turnover time and therefore carbon stocks; (7) among abiotic and biotic factors that regulate the carbon turnover time, only a few are considered in current modeling approaches (i.e., temperature, soil water content, $\mathrm{pH}$, particle size, and sometimes $\mathrm{C}$ and $\mathrm{N}$ interactions); and (8) although most models of soil $\mathrm{C}$ dynamics assume that the processes involved are linear, there are now many indications of nonlinear soil $\mathrm{C}$ dynamics processes linked to soil OM dynamics (e.g., prim-
\end{abstract}

ing). Farming practices, therefore, affect soil C stocks not only through carbon inputs but also via their effect on microbial and organomineral interactions, yet it has still not been possible to properly identify the main mechanisms involved in $\mathrm{C}$ loss (or gain). Greater insight into these mechanisms and their interdependencies, hierarchy and sensitivity to agricultural practices could provide future levers of action for $\mathrm{C}$ sequestration in soil.

\section{Introduction}

Increasing organic carbon stocks in agricultural soils has emerged as an effective means to improve soils, increase plant productivity, and delay the rise of atmospheric carbon dioxide and the rate of climate change while maintaining the quality of downstream ecosystems. The recent spotlight of the climate change issue has considerably renewed scientific interest in soil organic carbon, which is now seen as a main compartment of the global $\mathrm{C}$ cycle, thus providing opportunities for mitigation. In this context, the " 4 per 1000 initiative: soils for food security and climate" was launched in 2015. Considering that the total amount of organic carbon in soils at the global scale is about $2400 \mathrm{Gt}$ of $\mathrm{C}$ and that anthropogenic $\mathrm{CO}_{2}$ emissions are about $9.4 \mathrm{Gt}$ of $\mathrm{C}$ per year, a simple calculation suggests that an annual 4 per 1000 increase in the soil $\mathrm{C}$ stock could theoretically offset annual emissions $(2400 \times 0.04=9.6)$ (Minasny et al., 2017)

Meanwhile, this initiative has given rise to a scientific controversy (Amundson and Biardeau, 2018, 2019; van Groenigen et al., 2017; de Vries, 2018; Baveye et al., 2018a; Van- 


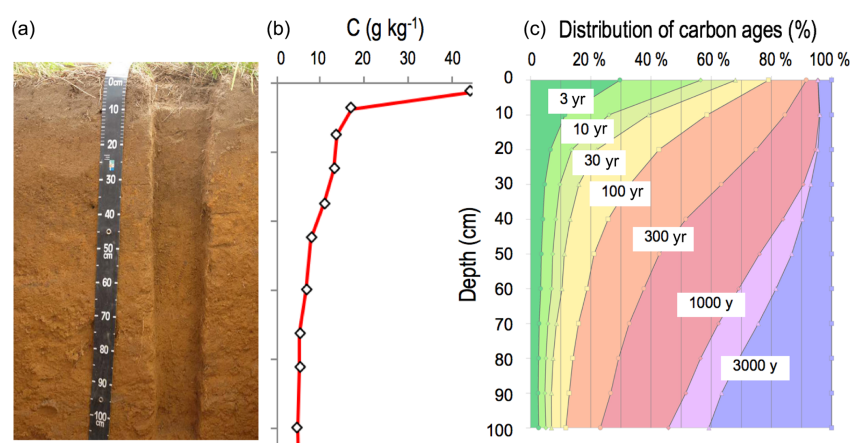

Figure 1. Grassland soil profile (a). The vertical distribution of organic carbon in this soil (b). A current distribution of carbon ages (c, based on data from Balesdent et al., 2018).

denBygaart, 2018; White et al., 2018; Minasny et al., 2018; Rumpel, 2019; Baveye and White, 2020; Loisel et al., 2019). Part of the criticism is focused on the potential for a political delay in the transition to renewable energies (Baveye et al., 2018b; Baveye and White, 2020), as well as on the calculation itself, which is based on several assumptions, some of which are actually highly debatable (e.g., the soil depth to be considered).

Other comments or questions have been more related to the processes underlying soil $\mathrm{C}$ storage. Is there an upper limit to $\mathrm{C}$ storage in soils? What is the expected turnover time of this carbon after its incorporation in soils? Is it possible to store more carbon without additional $\mathrm{N}$ and $\mathrm{P}$ inputs? Although substantial scientific knowledge exists on soil carbon dynamics, some uncertainty remains on these questions. Moreover, current soil C stocks are spatially highly variable, and factors that could explain this variability are not fully understood, although more knowledge in this area would be helpful to design soil C storage strategies more efficiently.

Last but not least, questions remain about farming practices which could potentially increase carbon stocks. Although there is consensus on practices that ensure additional $\mathrm{C}$ inputs in agricultural soils, such as exogenous organic matter input, moderate intensification of extensive grasslands, limiting residue exports, growing cover crops, promoting grass cover in vineyards, adopting agroforestry and growing hedges, etc., the outcomes of other strategies such as reduced tillage and liming are more unclear (Dignac et al., 2017).

The gap between agronomic trials and scientific knowledge on soil $\mathrm{C}$ dynamics is partly responsible for this limited understanding of interactions underlying the effects of farming practices on soil $\mathrm{C}$ stocks. In order to foster progress in this area and facilitate proper interpretation of experimental results, this paper aims to provide a comprehensive and upto-date review of processes that control soil $\mathrm{C}$ dynamics, a time-course representation of these processes, and their response to variations in major biotic and abiotic factors.

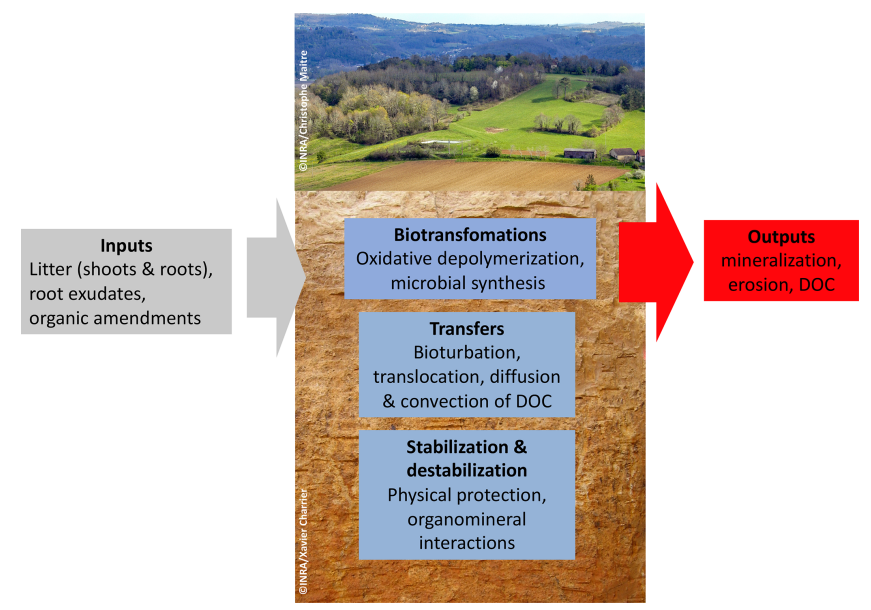

Figure 2. The different processes that control carbon storage in soils (DOC: dissolved organic carbon).

\section{Main processes controlling the organic matter nature, stock and dynamics in soils}

Soil organic carbon (Fig. 1) is distributed vertically with a strong concentration gradient decreasing from surface to depth: from $400 \mathrm{~g} \mathrm{~kg}^{-1}$ in organic "O" horizons at the surface of forest soils, via nearly $100 \mathrm{~g} \mathrm{~kg}^{-1}$ in the first centimeter of the organomineral horizon, to concentrations averaging less than $5 \mathrm{~g} \mathrm{~kg}^{-1}$ at $1 \mathrm{~m}$ depth (Oades, 1988). This element has a wide range of ages in soil from a few days to several thousand years old (Fig. 1) (Balesdent et al., 2018). The soil carbon stock is the sum of what remains of each past annual input, so it depends on incoming carbon fluxes, biotransformations and the stabilization duration prior to the release of this element from the soil, mainly in the form of $\mathrm{CO}_{2}$ produced by decomposer respiration. The main processes that regulate organic matter $(\mathrm{OM})$ dynamics in soils are summarized in Fig. 2.

\subsection{Carbon inputs into soil: nature and fluxes}

Organic matter entering the soil system is mainly synthesized by higher plants. It reaches the soil through the roots (dead roots or root exudates) or in the form of shoot litter and via unharvested aboveground plant parts. Regarding cultivated land, the soil carbon input flux is the net primary production of the ecosystem minus the exported crop production, losses from herbivory (production and respiration), and dissolved and particulate organic matter outputs. The harvested primary production is transformed, and some of it can subsequently be transferred to other soils as animal effluents (manure and slurry) or effluents and waste products from human activities (sewage sludge, compost from various sources, etc.). 


\subsubsection{Above- and belowground input fluxes}

The soil $\mathrm{C}$ input of unharvested aboveground plant-part (hereafter "restitution") fluxes can be estimated based on plant carbon allocation equations (allometric relationships) combined with carbon models. The harvest index (HI) for cultivated land is the harvested proportion of net primary production from shoots, while the rest is returned to the soil. Note, for example, that $\mathrm{HI}$ values of $45 \%-55 \%$ are commonly obtained for highly productive cereals (Fan et al., 2017). Genetic and agronomic optimization of yields generally increases the HI. It can, therefore, be said that, for a given crop production, carbon returns to soils increase with primary production, but the restitution or yield ratio decreases as the yield increases.

The belowground to aboveground biomass (root/shoot) proportion is an indicator that is closely dependent on environmental conditions while also being highly variable (0.10.3) (Bolinder et al., 1997; Poeplau and Katterer, 2017). However, a very important novel finding on soil OM (SOM) mechanisms is that belowground input flux (much less documented than inputs from leaves and stems) is considered to contribute more to soil organic matter through dead roots and rhizodeposition than aboveground litter input (Clemmensen et al., 2013; Rasse et al., 2005; Katterer et al., 2011). Rhizodeposition represents the contribution of carbon to the soil by living plants via roots. This may include root renewal, release of cells or tissue (epidermis, root hairs, cap cells), macromolecules such as mucilage and extracellular enzymes, or small molecules, i.e., exudates (Nguyen, 2003). Rhizodeposition is a series of processes generally related to the acquisition of water and nutrients by plants (including $\mathrm{P}, \mathrm{N}, \mathrm{K}, \mathrm{Fe}$ and $\mathrm{Mg}$ ). Carbon transfer from plants to symbiotic fungi is one of these processes. It is estimated that the rhizodeposition flux represents $20 \%$ to $50 \%$ of the net root production (Nguyen, 2003; Jones et al., 2009; Balesdent et al., 2011). Belowground inputs are still largely unknown, highly variable and constitute a definite but still relatively unexplored lever driving carbon storage in soil. The belowground proportion of primary production is generally greater when the soil conditions are limiting (water, nitrogen, phosphorus, iron).

For example, for a cereal producing $8.5 \mathrm{tDM} \mathrm{ha}^{-1}$ of grain (where DM represents dry matter), the aboveground restitution (stems, leaves) can be $7.5 \mathrm{tDM} \mathrm{ha}^{-1}$ (HI 53\%), containing $450 \mathrm{mg} \mathrm{g}^{-1}$ of carbon or $3.4 \mathrm{tC} \mathrm{ha}^{-1}$. In addition, $1.3 \mathrm{tC} \mathrm{ha}^{-1}$ of roots ( $18 \%$ of aboveground production) and $0.4 \mathrm{tCha}^{-1} \mathrm{yr}^{-1}$ of rhizodeposition (31\% of belowground production) are added. The annual input into the soil is about $5.1 \mathrm{tC} \mathrm{ha}^{-1} \mathrm{yr}^{-1}$ in this example. In grassland or fodder systems, a greater proportion of the aboveground parts are exported or grazed, and belowground inputs account for the majority of the soil inputs.

\subsubsection{Chemical nature of soil organic matter inputs}

The main plant compounds that reach the soil are the plant structural constituents. These primarily include cellulose compounds and hemicellulose compounds (neutral sugar polymers), as well as lignin compounds (phenolic compound polymers), pectin compounds (polymers containing charged sugars), proteins (structural or enzymes released by the roots), lipids from waxes, cuticles, bark and root cortexes. Plants also release secondary metabolites. They can be polyphenolic compounds, tannin compounds and a multitude of small molecules constituting root exudates (complex sugars, organic acids) (Kogel-Knabner, 2017). The small molecules probably have a greater impact on carbon dynamics through their effects on microorganisms and on organic matter $(\mathrm{OM})$ mobilization by their priming effect than a structural OM source has (Keiluweit et al., 2015). Dead tissue that reaches the soil does not have the same composition as living tissue, because the plant reallocates many metabolites and mineral elements during senescence (particularly sugars and nitrogen compounds) while mainly leaving structural compounds (Guiboileau et al., 2010). Green manure derived from freshly cut living tissue differs from other plant inputs in this respect. Microbial products are generally composed of the same molecules as plants products except for cellulose compounds and lignin compounds. Compared to plant $\mathrm{OM}$, microbial products are comparatively enriched in other polysaccharides, lipids, proteins, amino sugars, nucleic acids, chitin and a very diverse range of metabolites (Kallenbach et al., 2016).

Soil organic matter is generated from all of these plant or microbial molecules or their monomers (Kelleher and Simpson, 2006). Nonindustrial organic waste products (e.g., poultry or cattle manure, pig slurry, etc.) are composed of mixtures of plant or microbial molecules or their monomers, as well as animal-derived organic compounds, while compost and sewage sludge are enriched in microbial compounds (Senesi and Plaza, 2007; Larney and Angers, 2012).

In addition to the fresh and/or recently-derived organic matter described above, byproducts of incomplete combustion (plant coal from fires, soot from regional or global fallout), biomass pyrolysis products (terra preta, biochar (Lehmann et al., 2011), charcoal production residue and coal mine waste), and plastics may also be present. Moreover, soils may contain geogenic organic carbon, particularly when the parent rocks are organically rich, such as black shale, which blackens the soil color.

\subsection{Organic matter transformation in soil}

\subsubsection{Physical and chemical biotransformation protagonists: fauna and microorganisms}

Biochemical reactions that occur during OM decomposition are mainly induced by microorganisms (fungi and bac- 
teria), whether they are soilborne or associated with fauna (soil fauna and herbivores). The essentially mechanical action of soil fauna is often distinguished from the predominant biochemical action of microorganisms. Recent studies have highlighted the close complementarity of all living organisms in the soil with regard to OM transformation.

Macrofauna (earthworms, termites, ants, etc.) act by fragmenting the litter, incorporating it into the soil profile and mixing the soil within the profile by bioturbation (Bohlen et al., 2004). Soil transit through the digestive tract of macrofauna (mainly earthworms) promotes contact between microbes and OM. Digestion alters the chemical structure of OM: (i) by selective digestion of peptide compounds, which alters their stability (Shan et al., 2010); (ii) by biochemical modifications due to alternating extreme $\mathrm{pH}$ or redox conditions; or (iii) by physical modification of particles (Brauman, 2000). Many soil fauna groups are thus recognized as stimulating microorganism activity and soil organic matter biodegradation (Vidal et al., 2016; Brown, 1995).

Micro- and mesofauna (mites, springtails, Collembola, tardigrades, protozoa, etc.) mainly form a food web that regulates decomposing microorganisms; e.g., protozoa and bacteria-feeding nematodes tend to decrease the microorganism density (Bonkowski, 2004; Trap et al., 2016).

Microorganisms (fungi and bacteria) are the main drivers of OM chemical biotransformation. They represent the most taxonomically and functionally diverse living component of soil (Torsvik and Ovreas, 2002; Curtis and Sloan, 2005; Hättenschwiler et al., 2018). It is estimated that $1 \mathrm{~g}$ of soil can support up to 1 billion bacteria belonging to 1 million species (Gans et al., 2005) and dozens of meters of mycelial filaments belonging to 1000 fungal species (Bardgett et al., 2005; Buee et al., 2009). Microbial biomass is the mass of living microorganisms in soil and generally amounts to a few hundred grams of dry matter per square meter of soil, but most of the microbes are dormant or barely active (Lennon and Jones, 2011). The rhizosphere (soil zone near the roots) concentrates a large proportion of the soil's microbial activity (Nguyen, 2003). A systematic inventory of bacterial biodiversity (species richness) throughout France yielded an average of 1300 different genera at each sampling site - the richness variance could be explained by $\mathrm{pH}$, grassland, forest and agricultural land use, and the soil texture (Terrat et al., 2017). Microbial biomass is lowest in cultivated soil and is accompanied by lower $\mathrm{C}$ concentration in soil (Horrigue et al., 2016; Dequiedt et al., 2011).

\subsubsection{Biotransformation reactions}

Biotransformation reactions in soil are chemical reactions catalyzed by enzymes produced by living soil organisms, in particular millions of microorganism species. These are both degradation and synthesis reactions, while uncatalyzed chemical biotransformations are very rare.
The degradation reactions of organic compounds (socalled catabolic reactions) are mainly hydrolytic or oxidative depolymerization (Lehmann and Kleber, 2015). The incoming plant compounds are mainly large molecules (Fig. 3). These are cellulose, hemicellulose compounds, lignin, proteins, etc., all of which represent "substrates". Due to their large size, their depolymerization first takes place outside microbial cells (Burns et al., 2013). Co-location between substrates and microorganisms at the microbial habitat scale is essential for reactions to occur. Substrate and enzyme contact can take place by diffusion and advection of substrates and enzymes or by microorganism growth (mainly for fungi) and mobility (mainly for bacteria). In addition, local environmental conditions (oxygenation, $\mathrm{pH}$, water content, etc.) at the micrometer spatial scale must be favorable for microorganism activity (Chenu and Stotsky, 2002; Don et al., 2013; Pinheiro et al., 2015). In the particular case of fully or partially oxygen-depleted systems (so-called anaerobic conditions), oxygen cannot play its role as the final electron acceptor that accompanies $\mathrm{C}$ oxidation during degradation. Oxidative degradation can occur with other electron acceptors but with reaction rates that can be 10 times slower (Keiluweit et al., 2017; Klupfel et al., 2014).

The action of extracellular enzymes continues until smaller reaction products (sugars, phenolic compounds, amino acids, lipids smaller than around $600 \mathrm{Da}$ ) can be transported through the microbial cell membranes. The extracellular nature of reactions has several consequences. On the one hand, biodegradation has a high energy cost for organisms (e.g., transport of enzymes through cell membrane) and cells have to invest $\mathrm{C}, \mathrm{N}, \mathrm{P}$ and $\mathrm{S}$, while on the other hand, some compounds escape from the cells and are diluted in the soil solution or adsorb onto other organic or mineral compounds. Small molecules resulting from biodegradation can thus aggregate via weak bonds (hydrogen bonds or hydrophobic interactions) with each other to form supramolecular assemblies (Sutton and Sposito, 2005) or with minerals to form organomineral associations (Kleber et al., 2015; Kögel-Knabner et al., 2008).

Small-molecular-weight organic compounds (organic acids, sugars, amino acids) can be transported into the intracellular environment of microorganisms for further biotransformation. Oxidative degradation can continue until its ultimate stage when the elements are mineralized $\left(\mathrm{CO}_{2}\right.$, $\mathrm{NH}_{4}^{+}, \mathrm{H}_{2} \mathrm{O}, \mathrm{HPO}_{4}^{-}, \mathrm{SO}_{4}^{2-}$ ). The entire biodegradation chain is shown in Fig. 3.

Unlike oxidative degradation, synthesis of new organic molecules from small-molecular-weight organic compounds occurs in microorganism cells in so-called anabolic reactions. Inorganic ions taken up from the soil solution (orthophosphate, ammonium) are also involved in the synthesis of new molecules. These new molecules become cellular components or excreted metabolites (e.g., organic acids, polysaccharides, extracellular enzymes) and contribute to the soil OM pool. C incorporated by microorganisms and then 


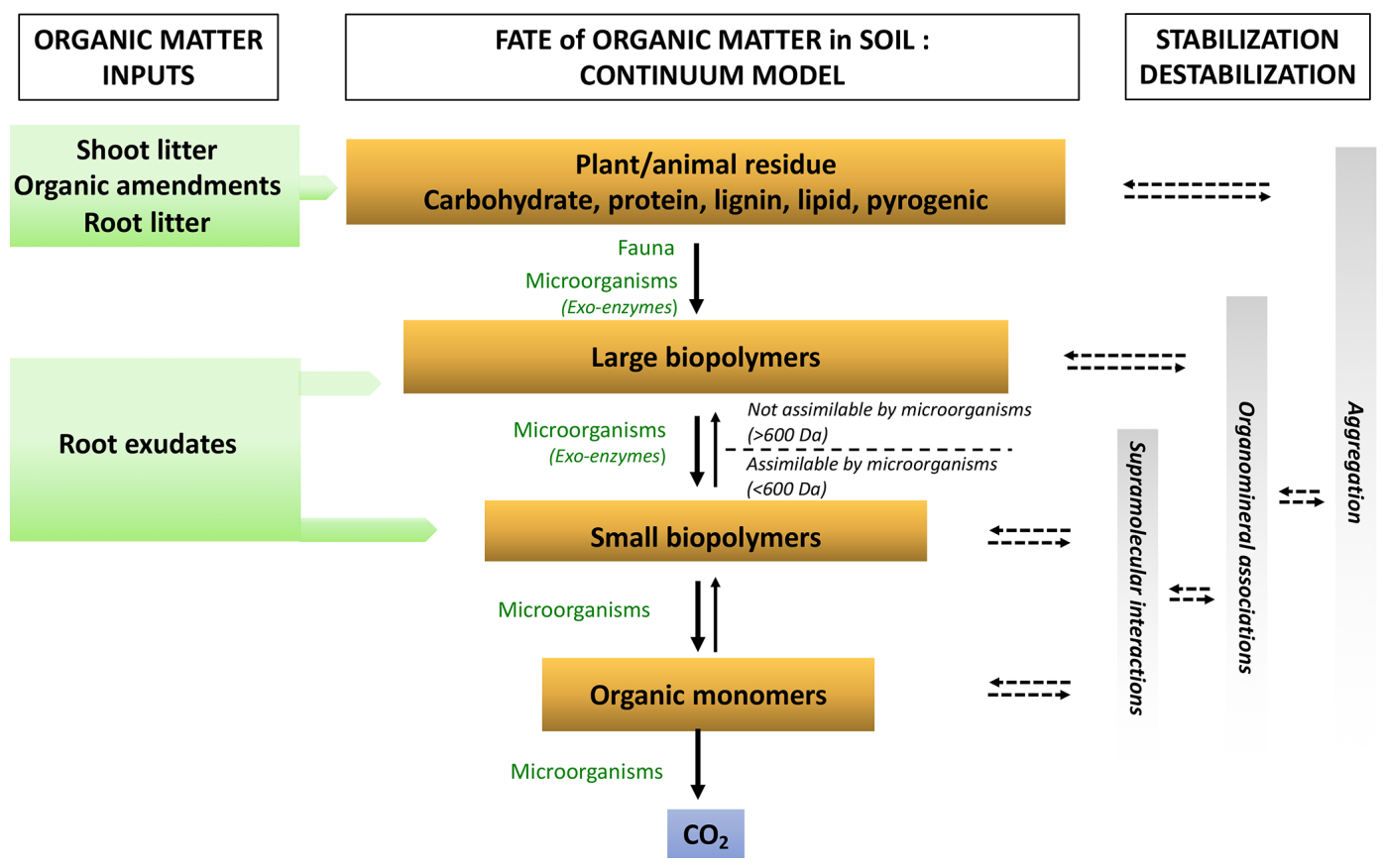

Figure 3. Representation of the soil OM biotransformation continuum model (adapted from Lehmann and Kleber, 2015). Organic matter enters the soil surface and deeper horizons in different forms. It is continuously degraded from plant and animal debris to the smallest molecules by the decomposer community. The size at which molecules can be absorbed by microorganisms is represented by $600 \mathrm{Da}$ (approximately $1 \mathrm{~nm}$ ). Simultaneously, the rising oxidation state of the OM carbons increases the water solubility of the compounds while also enhancing potential protection against further decomposition through greater reactivity to the OM (supramolecular associations) to mineral surfaces (organomineral interactions) and their incorporation into aggregates (aggregation). Solid arrows represent biotic processes and dashed arrows indicate abiotic processes.

reincorporated into soil OM is repeatedly recycled. It is important to highlight the recent finding that when a molecule is quickly consumed by microorganisms this does not necessarily mean that its $\mathrm{C}$ will be rapidly mineralized into $\mathrm{CO}_{2}$. The chemical stability or resistance to chemical attack of molecules reaching the soil is therefore not correlated with the soil's OM formation rate. The most biodegradable compounds have high long-term soil organic matter formation yields (Cotrufo et al., 2013).

\subsubsection{Nature, properties and size classes of soil organic matter}

Soil OM, therefore, consists of a continuum of organic compounds at different stages of the biotransformation reactions described above: from particulate organic matter (POM) to the elementary building blocks of living organisms (simple sugars, phenolic compounds, amino acids, peptides, fatty acids, organic acids, lipids). The simplest molecules can form random assemblies within supramolecular structures (Sutton and Sposito, 2005; Kelleher and Simpson, 2006) (Fig. 3).

Compounds of microbial origin (polysaccharides, proteins, etc.) have a longer lifespan in soil than structural compounds in plants (cellulose compounds, lignin compounds, etc.) (Amelung et al., 2008). This insight has led to the following very important finding: ultimately, microorganisms are the main producers of long-term stabilized organic compounds (relative to plants) (Derrien et al., 2006; Miltner et al., 2012; Kallenbach et al., 2016) (see stabilization processes in Sect. 2.3).

Oxidative depolymerization reactions are mainly hydrolytic processes. They systematically lead to a reduction in the size of molecules but also to an increase in their aqueous solubility and in their chemical reactivity. These properties are key to the behavior of soil solution compounds, particularly with respect to their ability to form organomineral associations. The speciation of some functional groups of soil organic matter is also $\mathrm{pH}$ dependent. One example is the carboxyl group, which is mainly in the form of $\mathrm{COOH}$ at $\mathrm{pH}$ below 4 but in the form $\mathrm{COO}-$ at $\mathrm{pH}$ above 5 . The reactivity of soil OM is thus highly pH dependent (Kleber et al., 2015).

Finally, the average proportions of the different soil OM types and their size ranges are summarized in Fig. 4. From an operational standpoint, $\mathrm{C}$ analysis of soil samples is performed on "fine" soil, which contains dry soil sieved to $2 \mathrm{~mm}$, i.e., mainly $\mathrm{C}$ from simple and complex biopolymers $(\sim 75 \%)$, particulate organic debris (including carbonized debris) $(\sim 20 \%)$, microorganisms $(\sim 2 \%)$, fauna $(<1 \%)$ 


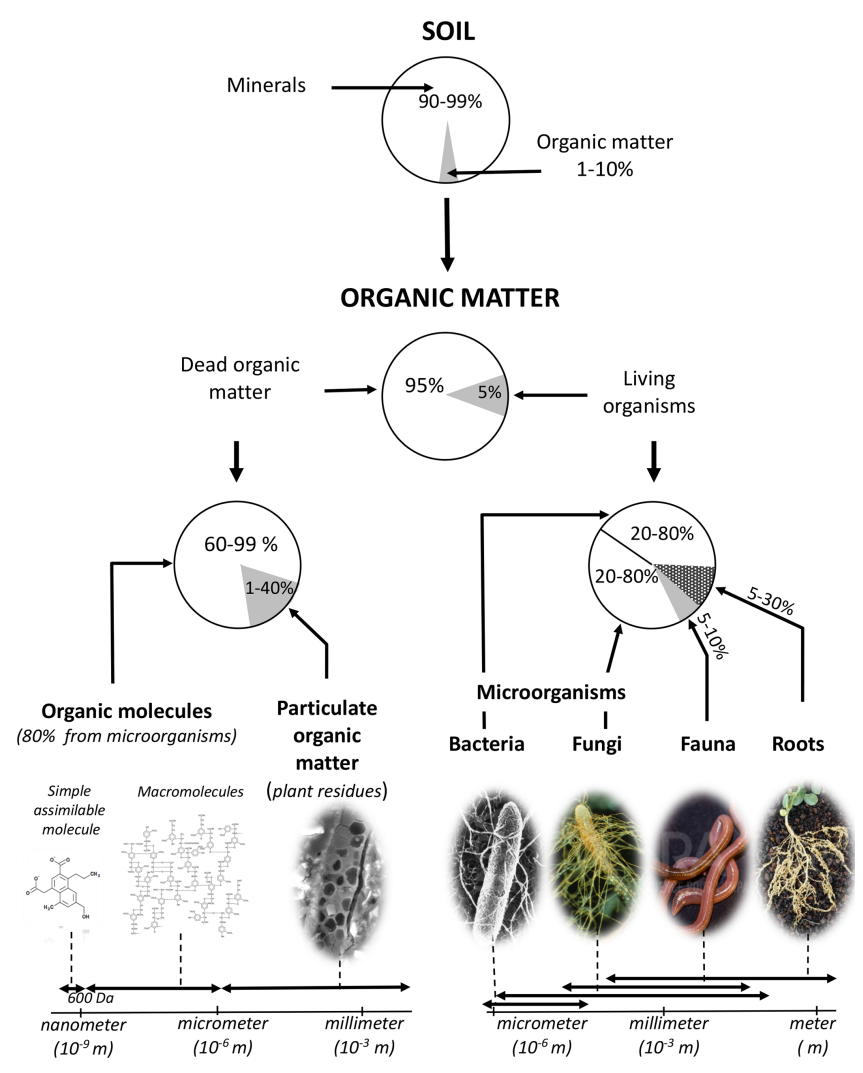

Figure 4. Nature, size range and indicative proportions of organic matter in $<2 \mathrm{~mm}$ soil. Organic matter makes up less than $10 \%$ of soil constituents. The stock of $\mathrm{C}$ in a soil is mainly made up of dead organic matter molecules mainly resulting from microbial activity; adapted from Calvet et al. (2011).

and the finest roots $(<2 \%)$. These proportions are approximate and vary greatly between soils and horizons.

\subsubsection{The progressive decomposition model at odds with historical concepts}

In the progressive decomposition conceptual model described above, soil OM consists of a range of organic fragments and microbial products of all sizes at different decomposition stages (Fig. 3). This mechanism is at odds with the historical "humification" model, proposing the formation of "humic substances" by progressive condensation of plant molecules and their decomposition products into macromolecules. Moreover, the different classes of humic compounds identified in the past (humic acids, fulvic acids, humins) do not correspond to molecules that exist in situ but rather to physicochemical rearrangements of smaller molecules during their extraction (Sutton and Sposito, 2005). These different concepts (humification, humic substances, humic and fulvic acids, humins), which have been revealed as deficient by modern soil OM characterization methods, should no longer be used by the soil science community
(Lehmann and Kleber, 2015) nor showcased in teaching courses (except to explain that it has been one step in the historical development of knowledge on soil OM).

The selective preservation model has also been invalidated by dating techniques, demonstrating that supposedly recalcitrant molecules are not specifically preserved in soil OM (Gleixner et al., 2001; Dignac et al., 2005; Amelung et al., 2008; Bol et al., 2009). Indeed, soil microbial communities (and implicitly the associated enzymatic repertoire) are able to degrade all types of substrate in almost any soil (Dungait et al., 2012). Soil OM preservation mechanisms are, therefore, not linked to its chemical recalcitrance but rather to other biological, physicochemical and structural factors (Schmidt et al., 2011), particularly its ability to associate with minerals (see Sect. 2.3.1).

\subsection{OM transfers within the soil profile}

Organic matter is transferred within the soil profile in particulate, colloidal or dissolved form. Transfer occurs mainly via pedoturbation or water transport.

Pedoturbation refers to the mixing of soil layers by physical processes in certain types of soil (frost, clay swelling and crack filling) but mainly by biological processes (bioturbation). Bioturbation occurs when particulate transport is linked to biological action, i.e., when soil fauna (e.g., earthworms, ants, termites, voles and moles) bury plant residue, gradually mix the soil or move mineral material to the surface from deep horizons (Lavelle et al., 2016). The mixing process decreases exponentially with depth and becomes negligible below $50 \mathrm{~cm}$ over decades (Jagercikova et al., 2015). Bioturbation is known to be more prevalent in permanent grasslands and fields under conservation agriculture than in conventional crop fields (Jagercikova et al., 2014).

Earthworms are essential actors in bioturbation as they ingest both organic matter (plant residue or other organisms, equivalent to $10-30 \mathrm{mg}$ of dry OM per gram of fresh earthworm biomass per day) and mineral particles (Curry and Schmidt, 2007) and mix several dozen tonnes of soil per hectare per year $\left(\mathrm{tha}^{-1} \mathrm{yr}^{-1}\right)$ (Blouin et al., 2013). Earthworms bury these organomineral mixtures in the soil, excrete them along their galleries and, for some species, bring them to the surface as casts (Don et al., 2008). These biostructures represent hotspots of OM enriched in mucus that contribute to the stability of organomineral aggregates (Coq et al., 2007; Shan et al., 2010) and to C stabilization (Martin et al., 1990). It has been shown that the presence of earthworms can increase the C stock in soil by $30 \%$ (Zangerle et al., 2011). Earthworms belong to different ecological groups, with each group occupying a specific ecological niche and influencing soil aggregation and C turnover differently (Frazão et al., 2019).

Water that flows in the soil pore space is also a vector for vertical OM transport in the soil. By definition, this involves the transfer of particles less than $2 \mu \mathrm{m}$ via "lessivage" 
(Jagercikova et al., 2014) and of organic matter less than $0.45 \mu \mathrm{m}$. OM of less than $0.45 \mu \mathrm{m}$ is called dissolved organic matter (DOM). This OM is free or adsorbed on minerals and colloids smaller than $450 \mathrm{~nm}$, co-precipitated with oxyhydroxides smaller than $450 \mathrm{~nm}$ or complexed with metals. DOM molecules are generally small (less than $100 \mathrm{kDa}$, Fig. 4 molecules shown on the bottom left), thus facilitating their diffusion. Water draining the upper soil horizons (organic horizons and surface mineral horizons) can have a high DOM content, while water draining the soil at depth generally has a low DOM content. DOM concentrations are also often correlated with the soil texture, with sandy soil solutions often having a higher DOM content than clay soils (under equivalent climatic conditions). There may also be marked seasonal variations in DOM (Kleber et al., 2015). The DOM content thus depends on site-specific soil, climate and land management conditions, but experimental data on DOM mechanisms and processes in agricultural soils are still sparse (Gmach et al., 2020).

\subsection{Soil organic matter stabilization}

\subsubsection{Organomineral interactions}

Organomineral interactions have become recognized in the last 10 years as a key factor in stabilizing organic matter in soil (Schmidt et al., 2011; Lehmann and Kleber, 2015; Mathieu et al., 2015). Soil minerals account for over $90 \%$ of the solid constituents in soil (Fig. 4). The smallest minerals, mainly contained in the particle size class of less than $2 \mu \mathrm{m}$ (clay particle size fraction, classified as "clays" by agronomists), are highly effective in protecting OM. This particle size class includes a wide variety of minerals. Those with the greatest surface reactivity are most involved in organomineral associations, and those with the highest specific surface area lead to greater quantities of stabilized OM. These include phyllosilicates (clay minerals, classified as clays by mineralogists), different forms of metal oxyhydroxides and poorly crystalline aluminosilicates (Basile-Doelsch et al., 2015; Kleber et al., 2015). Regardless of the nature of the minerals, the OM they stabilize is mostly made up of small molecules derived from microbial products (Miltner et al., 2012; Clemmensen et al., 2013; Cotrufo et al., 2015; Lavallee et al., 2018).

These minerals and poorly crystalline phases protect organic compounds from enzymatic degradation through two main mechanisms (Kleber et al., 2015):

1. Adsorption on the surface of minerals is the first identified process (Kleber et al., 2007). When the adsorption affinity of an organic functional group for a mineral surface is greater than its affinity for an active enzyme site, oxidative degradation through enzymatic reactions cannot take place. Adsorption sites are not evenly spread over mineral surfaces. Organic compounds are adsorbed in patches but do not cover the entire surface of the particle (Vogel et al., 2014; Remusat et al., 2012).

2. Co-precipitation is the formation of secondary mineral phases in the presence of OM. The size of these mineral phases ranges from one to a few dozen nanometers (Tamrat et al., 2018; Eusterhues et al., 2008; Levard et al., 2012; Rasmussen et al., 2018; Mikutta et al., 2006; Kleber et al., 2015; Torn et al., 1997; Tamrat et al., 2019). Allophanes, Fe and Al oxyhydroxides are the most commonly described mineral phases. They are often associated with chelates (organic ligands associated with a Fe or Al metal cation) in low-pH soils (Rasmussen et al., 2018). A molecular structure of nano-sized co-precipitates of inorganic oligomers with organic compounds has also been recently proposed (Tamrat et al., 2019). Poorly crystalline mineral phases can also be dissolved by the action of organic ligands secreted by roots. Organic compounds then lose their mineral protection and can be used by microorganisms (Keiluweit et al., 2015).

A third process, i.e., cationic bridging by di- or trivalent ions, can also play an important role in OM stabilization in some soils. When this involves bridging between a mineral surface and an organic functional group - both negatively charged - it is referred to as "ternary complexation". In high$\mathrm{pH}$ and arid soils, cationic bridging with $\mathrm{Ca}^{2+}$ ions tends to override other organomineral bonds (Rasmussen et al., 2018; Rowley et al., 2018).

A conceptual representation of carbon stabilization by adsorption alone (above-cited point 1) on clay minerals has given rise to the saturation concept (Hassink, 1997), whereby mineral surfaces are assumed to accommodate a limited amount of carbon, thus limiting soil carbon storage. However, the concept has yet to be sufficiently validated to be operational (West and Six, 2007), and the mechanism itself has been invalidated by certain observations (Vogel et al., 2014). In view of recent advances in knowledge of organomineral interactions, the saturation concept could now be revisited from a more mechanistic angle.

\subsubsection{Soil structure and aggregation}

Soil particle aggregation processes affect the OM mineralization rate (Rovira and Greacen, 1957). For example, the turnover time of $\mathrm{C}$ in microaggregates $(<50 \mu \mathrm{m})$ is greater than that in macroaggregates $(>50 \mu \mathrm{m})$ (Golchin et al., 1994; Besnard et al., 1996; Six et al., 1998, 2002; Balesdent et al., 2000; Chevallier et al., 2004). However, the structural difference between micro- and macro-aggregates may not be the only factor underlying the difference in OM mineralization rate, because (i) the nature of OM in these two entities may differ, and (ii) the lifespan of the macro- and microaggregates, which regulate the OM trapping time, is not the same (Plante et al., 2006). Nevertheless, aggregates, and es- 
pecially microaggregates, are often used as fractions indicating the "degree" of physical protection of carbon. Conceptual models describe the $\mathrm{C}$ dynamics in the different aggregates by considering the formation-destruction cycles of the aggregates, but their parameterization remains complex (Stamati et al., 2013).

The action of decomposers on their organic substrates (see Sect. 2.2.1) takes place in the soil pore network in microhabitats. Since the smallest bacteria are in the micrometer range, the soil structure and its heterogeneity controls accessibility and biodegradation at the micrometer spatial scale (Juarez et al., 2013) and may be related to different microbial communities in these habitats. The rate of mineralization of simple substrates thus partly depends on the size of the pores in which they are located (Killham et al., 1993; Ruamps et al., 2013). The geometry of the mineral particle associations creates microsites (nanometric to micrometric) in which OM is protected from enzymatic action. Within a microsite, regardless of whether or not organic compounds are directly bound to mineral surfaces, oxidative depolymerization (see Sect. 2.2.2) can be significantly slowed down by limiting enzyme access and $\mathrm{O}_{2}$ diffusion (Zimmerman et al., 2004; Chevallier et al., 2010; Keiluweit et al., 2017).

New models include an explicit 2D or 3D description of the pore network based on tomographic images (Monga et al., 2008, 2014; Blair et al., 2007; Falconer et al., 2015; Pajor et al., 2010; Resat et al., 2012; Vogel et al., 2015). They operate in short time steps and have been validated for simplified systems, but they cannot be used at the plot level because they require many parameters which are not available at this scale and would also be too computationally demanding. On the other hand, they should make it possible to prioritize the $\mathrm{C}$ dynamics control variables so as to be able to define soil structure descriptors other than those currently used in plotscale models.

\subsection{Soil carbon outputs}

\subsubsection{OM transfers and outputs: erosion and DOC losses}

When no longer counterbalanced by pedogenesis, erosion is the major factor in soil degradation at the decadal timescale. It is mainly related to soil surface runoff and is therefore highly dependent on the climate, topography and land-use conditions. Wind erosion can also be significant, especially in arid regions. In undisturbed natural systems, material loss through erosion is generally offset by pedogenesis (Doetterl et al., 2016), whereas agricultural use increases erosion rates by 100 -fold by removing natural vegetation and reducing surface OM in litter (Montgomery, 2007). With agricultural expansion, conservation agriculture has been adopted in many parts of the world to reduce soil erosion. The high spatiotemporal variability in soil erosion is thus associated with the land-use and management history. Surface horizons have been substantially depleted in $\mathrm{C}$ as a result of soil erosion (Lal, 2001). On a global scale, the quantity of soil C exported by lateral erosion is estimated at $0.3-1 \mathrm{GtC}^{-1}$. Not considering the contribution of erosion to $\mathrm{C}$ flux budgets between soils and the atmosphere is a major source of error in the interpretation of soil $\mathrm{C}$ dynamics model outputs (Chappell et al., 2016). C transferred laterally by erosion is lost at the pedon scale, but the integration of processes at the watershed scale (detachment, transport, sedimentation, burial in lowland areas) results in $\mathrm{C}$ budgets that often give rise to debate regarding $C$ sinks and sources (Doetterl et al., 2016; Mulder et al., 2015).

Studies are lacking on the link between erosion and its effect on DOC fluxes. Vertical DOC fluxes measured in various soils and land-use conditions ranged from 0.4 to $5 \mathrm{~g} \mathrm{C} \mathrm{m}^{-2} \mathrm{yr}^{-1}$. Fluxes at the catchment scale were in the same range (0.2 to $2 \mathrm{~g} \mathrm{C} \mathrm{m}^{-2} \mathrm{yr}^{-1}$ ) (Doetterl et al., 2016). When integrated on a global scale, $\mathrm{C}$ exports via DOC flux could be estimated at around $0.7 \mathrm{Gt} \mathrm{yr}^{-1}\left(0.05 \mathrm{tC} \mathrm{ha}^{-1} \mathrm{yr}^{-1}\right.$ times $15 \times 10^{9} \mathrm{ha}$ ).

\subsubsection{OM mineralization}

Mineralization is the result of the respiration and excretion of the inorganic products of $\mathrm{OM}$ degradation $\left(\mathrm{CO}_{2}, \mathrm{NH}_{4}^{+}\right.$, $\mathrm{H}_{2} \mathrm{O}, \mathrm{HPO}_{4}^{-}, \mathrm{SO}_{4}^{2-}$ ) by organisms. Carbon mineralization is almost exclusively intracellular, despite the fact that extracellular catabolism of glucose has been observed (Kéraval et al., 2016). From a quantitative standpoint on a global scale, soils emit 10 times more $\mathrm{CO}_{2}$ from autotrophic (roots) and heterotrophic (microorganisms and fauna) respiration than human activities (IPCC, 2013). On a microscale, the carbonuse efficiency by microorganisms (or CUE), for a given substrate, is the quantity of microbial $\mathrm{C}$ formed in relation to the consumed $\mathrm{C}$. The microbial production is estimated to be 0.3 to 0.4 times the plant material input into the soil (Sinsabaugh et al., 2014). This CUE varies according to (i) the microbial species and their physiology (ii) the availability of nutrient resources $(\mathrm{N}, \mathrm{P}, \mathrm{S}$, etc.) required for microbial metabolism, (iii) interactions with the soil matrix and associated energy costs, and (iv) the physical soil conditions (temperature, $\mathrm{pH}$, humidity, etc.) (Manzoni et al., 2012; Geyer et al., 2016; Lashermes et al., 2016; Mooshammer et al., 2014). It is also likely to change according to the climatic and atmospheric conditions (Schimel, 2013; Allison et al., 2010; Sistla et al., 2013).

\section{Time-dependent processes: dynamic representations}

\subsection{Kinetics, characteristic times, turnover, balance and mathematical modeling}

The soil carbon pool is subject to permanent renewal. It is mathematically represented as a "dynamic system". Changes in the organic carbon stock can be described by a general 
differential equation:

$\mathrm{dC} / \mathrm{d} t=I-k \mathrm{C}$,

where $\mathrm{C}$ is the carbon stock $\left(\mathrm{tCha}^{-1}\right), t$ the time (year), $I$ the input $\left(\mathrm{tCha}^{-1} \mathrm{yr}^{-1}\right)$ and $k$ the proportion of mineralized carbon (or lost by erosion) per unit of time $\left(\mathrm{yr}^{-1}\right) . I$ is not necessarily constant. $k$ is not fixed and is dependent on the soil conditions, quantity and nature of the carbon stock. $k$ is the mineralization rate (often considered constant), and $k \mathrm{C}$ is the mineralization flux (respiration) (Elzein and Balesdent, 1995).

The system is at equilibrium (as an annual average) if the input and output fluxes are equal $(\mathrm{dC} / \mathrm{d} t=0$ and $I=k \mathrm{C})$. The system is at steady state if these fluxes, $I$ and $k \mathrm{C}$, are equal and constant. The term "turnover time" (year) commonly refers to the ratio of total carbon stock to the input or output flux (Eriksson, 1971). In steady-state systems, turnover time, mean age and mean transit time are synonymous terms. The term "residence time" (year) is used to describe the age of the $\mathrm{C}$ in the output flux, the age of the $\mathrm{C}$ stock or the turnover time. Hence the term is ambiguous. Sierra et al. (2017) discouraged its use in carbon cycle research.

Storage $(\mathrm{dC} / \mathrm{d} t>0)$ is the result of increased $I$ inputs or a reduced $k$ mineralization rate. The increase in carbon stock over a year cannot be greater than $I$. Conversely, the system $\mathrm{C}$ stock decreases if $\mathrm{dC} / \mathrm{d} t<0$. However, the average $k$ value masks the high heterogeneity in carbon turnover times. Isotopic tracing and soil respiration monitoring have helped monitor the fate of plant compound inputs in the soil at daily to millennial time steps (Balesdent et al., 2018; Mathieu et al., 2015). Most of these inputs are mineralized and transformed into microbial products in less than a year or a few years for ligno-cellulosic compounds. The transformation products (10\%-20\% of the carbon supply) are protected and mineralized very slowly over several decades. Figure 5 provides a numerical example of the fate of organic carbon reaching the soil.

The soil carbon stock is the sum of the remains of all of these past annual inputs. Several kinetic parameters can be calculated. In the example in Fig. 5, the OM mineralization rate is $0.11 \mathrm{yr}^{-1}$ (ratio of total input flux divided by total pool size). The vast majority of the carbon ( 37.5 over $\left.45 \mathrm{t} \mathrm{C} \mathrm{ha}^{-1}\right)$ consists of long-standing $\mathrm{C}$. The average age of the carbon is 42 years. These slow kinetic parameters cannot be explained by deterministic laws (e.g., enzymatic kinetics laws) but rather could be modeled by statistical approaches integrating complex functioning. Finally, dating methods have confirmed that organic materials can be inherited from a distant past of several decades (Mathieu et al., 2015).

Characteristic OM formation times are therefore long (several decades); OM currently present is inherited from past generations. Strictly speaking, kinetic representations should be based on continuous mathematical formalisms to predict time-course variations in carbon stocks. In practice, however, compartmentalization approaches are used in conventional models (Bosatta and Agren, 1995). While remaining fairly faithful to reality, they enable the simplification of mathematical formalisms via discretization kinetics.

\subsection{Nonlinear processes}

\subsubsection{Linear and nonlinear processes}

Conventional models (Hénin and Dupuis, 1945; Jenkinson and Rayner, 1977; Parton et al., 1987; Andriulo et al., 1999) consider that parameters of the OM fate are independent of the input flux and OM quantities. This results in first-order differential equations $(\mathrm{dC} / \mathrm{d} t=I-k \mathrm{C}$ with $k$ independent of $\mathrm{C}$, Eq. 1) and exponential kinetics. These models are considered linear: dual inputs result in twofold increases in OM amounts and compartments fill or empty at their characteristic rate. However, there are now many indications of nonlinear soil $\mathrm{C}$ dynamics processes linked to the soil OM dynamics (Liyanage et al., 2020; Montagnani et al., 2019; Banegas et al., 2015; McNicol and Silver, 2015; Chen et al., 2013; Wen et al., 2012; Bisigato et al., 2008; Keiluweit et al., 2015) (Table 1).

A major driver of nonlinear behaviors is the facts that $\mathrm{OM}$ is not homogeneously distributed and that plant inputs, microorganisms and dead OM are not co-located. Consequently, microorganisms might not be able to access a potential substrate because of spatial separation (Vogel et al., 2015; Nunan et al., 2020). Since they depend on local concentrations, nonlinear process parameters are dependent on the observation scale (i.e., the aggregate, horizon or profile scale), on root distances, etc. The dynamics are not the same in situ and in homogenized in vitro systems. In vitro they depend on the experimental design and duration. This could likely explain the high discrepancy in the literature with respect to the carbon dynamics processes, mechanisms involved and their broad quantification range. Although in vitro experiments help to gain insight into the mechanisms involved, in situ experiments and observations at the square meter or plot scale, and at the decadal timescale, are obviously more relevant for addressing the carbon storage issue. Nonlinear processes have yet to be incorporated into operational $\mathrm{C}$ dynamics models. The saturation concept (see Sect. 2.4.1), which typically takes the impact of the mineral-to-OM ratio on carbon stabilization into account, also leads to a nonlinear behavior.

\subsubsection{Priming effect}

A major nonlinear effect is the so-called "priming effect" (Fontaine et al., 2007; Kuzyakov et al., 2000; Sallih and Bottner, 1988). In short, the supply of complex decomposable substrates provides competent microorganisms with the energy resources required to biodegrade stabilized OM. Typically, the soil OM turnover time is thus shorter in soil zones 
(a)

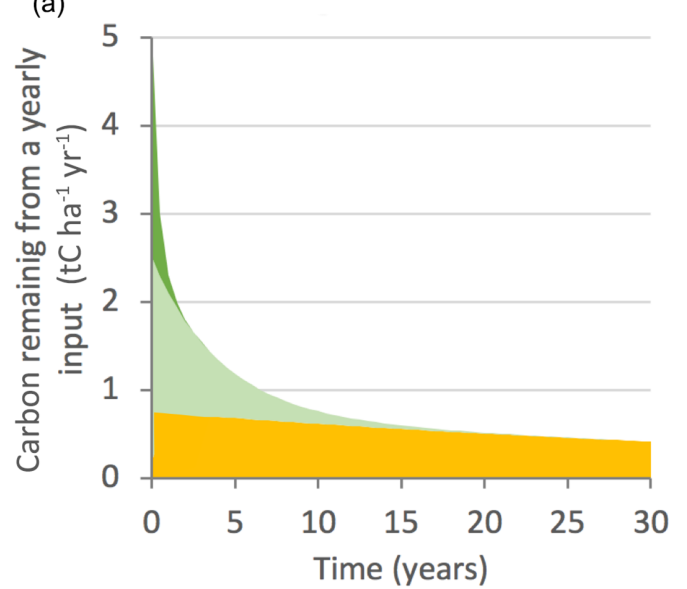

(b)

\begin{tabular}{lcccc}
\hline Kinetic pool & $\begin{array}{c}\text { Input } \\
\text { flux }\end{array}$ & $\begin{array}{c}\text { Mean } \\
\text { turnover } \\
\text { time }\end{array}$ & Pool size \\
\hline tC ha $^{-1} \mathbf{~ r ~}^{-1}$ & yr & tC ha $^{-1}$ \\
\hline Fast & 2.5 & 0.2 & 0.5 \\
\hline Intermediate & 1.75 & 4 & 7.0 \\
\hline Slow & 0.75 & 50 & 37.5 \\
\hline Total & 5.00 & 9 & 45.0 \\
\hline Old C & & 5000 & 10
\end{tabular}

Figure 5. (a) Simplified kinetic representation of the fate of plant organic inputs in soil (single input event, here $5 \mathrm{tC} \mathrm{ha}^{-1} \mathrm{yr}^{-1}$ ). The kinetics are divided into three mineralization phases: fast, intermediate and slow. Organic matter can be divided into three corresponding pools, the size of which is represented in the figure by the colored areas. The sizes of the pools inherited from the inputs at year 0 decrease progressively with their own kinetics over 30 years. (b) Pool sizes were calculated based on 30 years of yearly inputs (with fluxes between pools). The numerical values are typical of the $0-30 \mathrm{~cm}$ layer of temperate crops. Old carbon represents organic material inherited from a distant past.

Table 1. Possible nonlinear mechanisms of carbon decomposition or accumulation. Due to these mechanisms, decomposition rates are dependent on the amounts of carbon supplied or present. These processes can interact with each other.

\begin{tabular}{l}
\hline Main nonlinear mechanisms \\
\hline Effect of organic matter on physical properties that affect biodegradation rates: \\
- water properties (porosity, wettability, evaporation, mulch) \\
- ground temperature (porosity, thermal conductivity, albedo, mulch) \\
\hline Minerals or organic matter ratio modulating carbon stabilization \\
\hline Physical protection ("glue” role of organic matter and microbial polysaccharides) favoring \\
organomineral associations \\
\hline Exudation of complexing organic acids that destabilize organomineral associations \\
\hline Priming effect: stimulation of the biodegradation of stabilized organic matter by the energy \\
supply from fresh matter \\
\hline Carbon-use efficiency depending on nutrients available to microorganisms \\
\hline Toxicity of biodegradation byproducts to microbes (e.g., antibacterial litter, phenols) \\
\hline Organic matter resources for fauna that promote organomineral stabilization (earthworms) \\
\hline
\end{tabular}

that receive substantial inputs, such as on the surface relative to deep horizons. Except in cases of the burial of exogenous OM (which is considered to represent a risk of destabilization of pre-existing OM especially in deep horizons), the rhizosphere is the main soil compartment concerned by priming. The rhizosphere priming effect (RPE) is defined as the stimulation (or suppression) of OM decomposition by live roots and associated rhizosphere organisms as compared to SOM decomposition from rootless soils under the same environmental conditions. Findings of studies conducted in plant growth chambers and glasshouses indicate that the magnitude of the RPE varies widely, ranging from $380 \%$ enhance- ment (positive RPE) to $50 \%$ reduction (negative RPE) as compared to basal respiration from root-free soils (Cheng et al., 2014). These RPE levels demonstrate that rhizosphere processes are major drivers of SOM mineralization. Yet the RPE does not necessarily result in an ultimate decline of total OM, because the overall input of organic materials from the rhizosphere may compensate for the enhanced mineralization of accessible OM (Cheng et al., 2014). Priming mechanisms may also be linked to complex combined bioticabiotic mechanisms, whereby root exudates promote carbon loss by releasing organic compounds from protective associations with minerals (Keiluweit et al., 2015). Priming effect 
mechanisms are thus crucial in the dynamics of $\mathrm{C}, \mathrm{N}$ and $\mathrm{P}$ elements, and they highlight that carbon storage is not proportional to the inputs.

\subsection{Renewal rates at the soil profile scale: deep C dynamics}

Historical studies on dynamic representations of $\mathrm{C}$ have mainly focused on the soil layer considered by agronomists, i.e., $0-30 \mathrm{~cm}$ depth. However, there is growing interest in understanding the subsoil mechanisms involved, because half of the soil carbon is located below $30 \mathrm{~cm}$ depth (Mulder et al., 2016) (Jobbagy and Jackson, 2000; Hiederer and Köchy, 2011). Carbon- $14\left({ }^{14} \mathrm{C}\right)$ dating and natural tracing by ${ }^{13} \mathrm{C}$ have shown that the median age of carbon at $1 \mathrm{~m}$ depth is beyond 1000 years (Fig. 1). The renewal rate describes the quantity of new $\mathrm{C}$ that has been stored for a period of time. Renewal is $7-10$ times slower in the $30-100 \mathrm{~cm}$ layer than in the 0-30 cm layer (Mathieu et al., 2015; Balesdent et al., 2017,2018 ), but deep carbon is not inert. The above studies revealed that on average the $30-100 \mathrm{~cm}$ layer contains $25 \%$ of the "young" carbon stock (i.e., younger than 20 years) in the $0-100 \mathrm{~cm}$ layer in cultivated soils and $15 \%-20 \%$ in permanent grassland and forest soils (Fig. 6). Several studies have reported significant effects of land-use changes or agricultural practices on deep soil carbon, including a decrease in $\mathrm{C}$ through the cultivation of grasslands or forest areas (Guo and Gifford, 2002) and an increase when forests are converted to pasture (Stahl et al., 2017).

\section{Control of $\mathrm{C}$ turnover times in soil: biotic and abiotic factors}

The mechanisms described above are expressed to different extents in soil as a function of a series of 10 main factors that control their intensity. These factors are comprehensively presented in Wiesmeier et al. (2019). Here we propose a summary of the co-dependencies of these factors (Table 2) by focusing on carbon turnover time variation factors (but variations in stocks also depend on incoming carbon fluxes that are not considered here). In steady-state systems, the turnover time is equivalent to the mean age of $\mathrm{C}$ leaving the system (where age is the duration between the time when $\mathrm{C}$ enters the soil and the observation time), which is a more intuitive concept (Sierra et al., 2017).

Incoming $\mathrm{C}$. The nature of incoming $\mathrm{C}$, particularly its biodegradability, has a counterintuitive effect on carbon turnover times (see the progressive decomposition model in Sect. 2.2.2). The nature of $C$ affects turnover times through the microbial carbon-use efficiency (CUE) and organomineral interactions.

Temperature. Temperature is a major factor, among the best quantified, with mineralization rates rising twofold to threefold at every $10^{\circ} \mathrm{C}$ increase, but this effect depends on

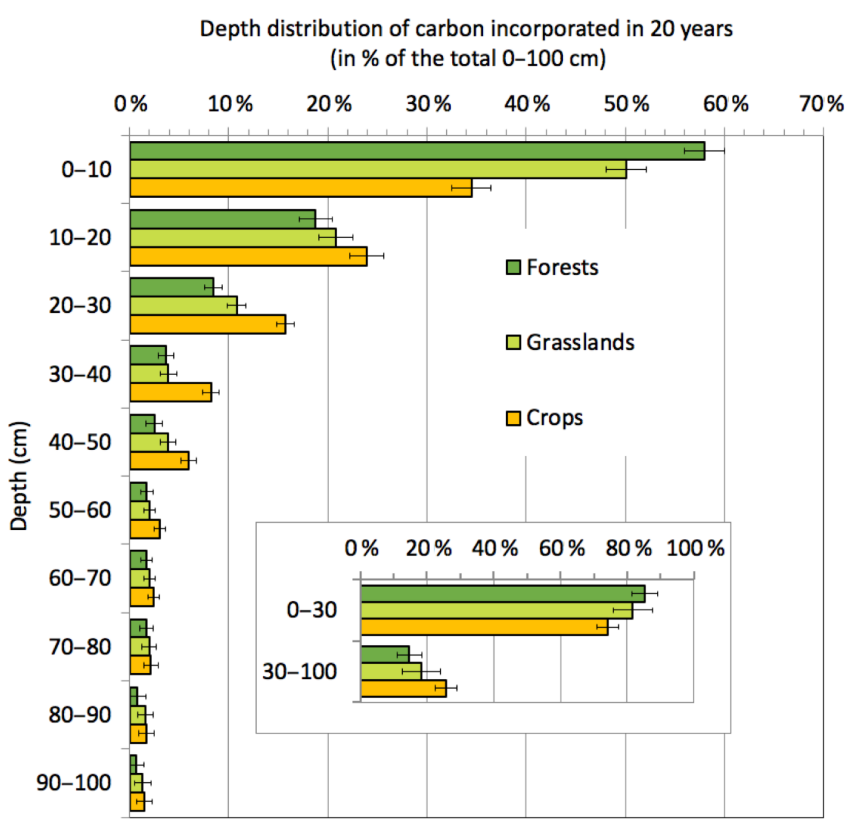

Figure 6. Vertical distribution of carbon incorporated by plant matter in the soil in 20 years under average temperate conditions. The data are from the quantification of a recent incorporation of atmosphere-derived carbon atoms into whole-soil profiles through a meta-analysis of changes in stable carbon isotope signatures at 112 grassland, forest and cropland sites (across different climatic zones) from 1965 to 2015 . The quantity (in $10 \mathrm{~cm}$ increments) is expressed as a proportion of the total $\mathrm{C}$ incorporated in the first meter of soil. The value is a regression mean estimated from climate and land-use conditions. The error bars represent the $95 \%$ confidence interval of the estimate. (Based on data from Balesdent et al., 2018.)

the soil, in particular its particle size distribution. Microbial activity breaks down quickly at very high temperatures.

Water content. As the soil water content increases, mineralization rates increase linearly with moisture to a maximum (reached at around $20 \%-50 \%$ of the volumetric soil water content according to the models, Sierra et al., 2015), followed by a plateau and a decrease caused by the oxygen deficit. The alternating drying-rewetting cycles accelerate mineralization.

The partial pressure of oxygen. In saturated environments, if the environment becomes anaerobic, microorganisms tend to use alternative electron acceptors such as nitrate, ferric iron and sulfate. The degradation of ligno-cellulosic debris is slowed or even stopped. However, there is no evidence of temporary anaerobic effects on carbon storage. Anaerobic environments are also unfavorable for roots, wildlife or microorganism activity. Plowing is often considered to accelerate biodegradation by aerating the soil, but tillage-induced $\mathrm{CO}_{2}$ release ends after a few days (Rochette and Angers, 1999). 
Table 2. Mechanistic analysis of factors influencing the carbon turnover time in soil (Fontaine et al., 2011; Schmidt et al., 2011; Kallenbach et al., 2016; Sinsabaugh et al., 2013; Rasmussen et al., 2018; Northup et al., 1995; Averill et al., 2014; Keiluweit et al., 2015; Bonneville et al., 2011). References for RothC and Century are Coleman et al. (1997) and Parton and Rasmussen (1994), respectively.

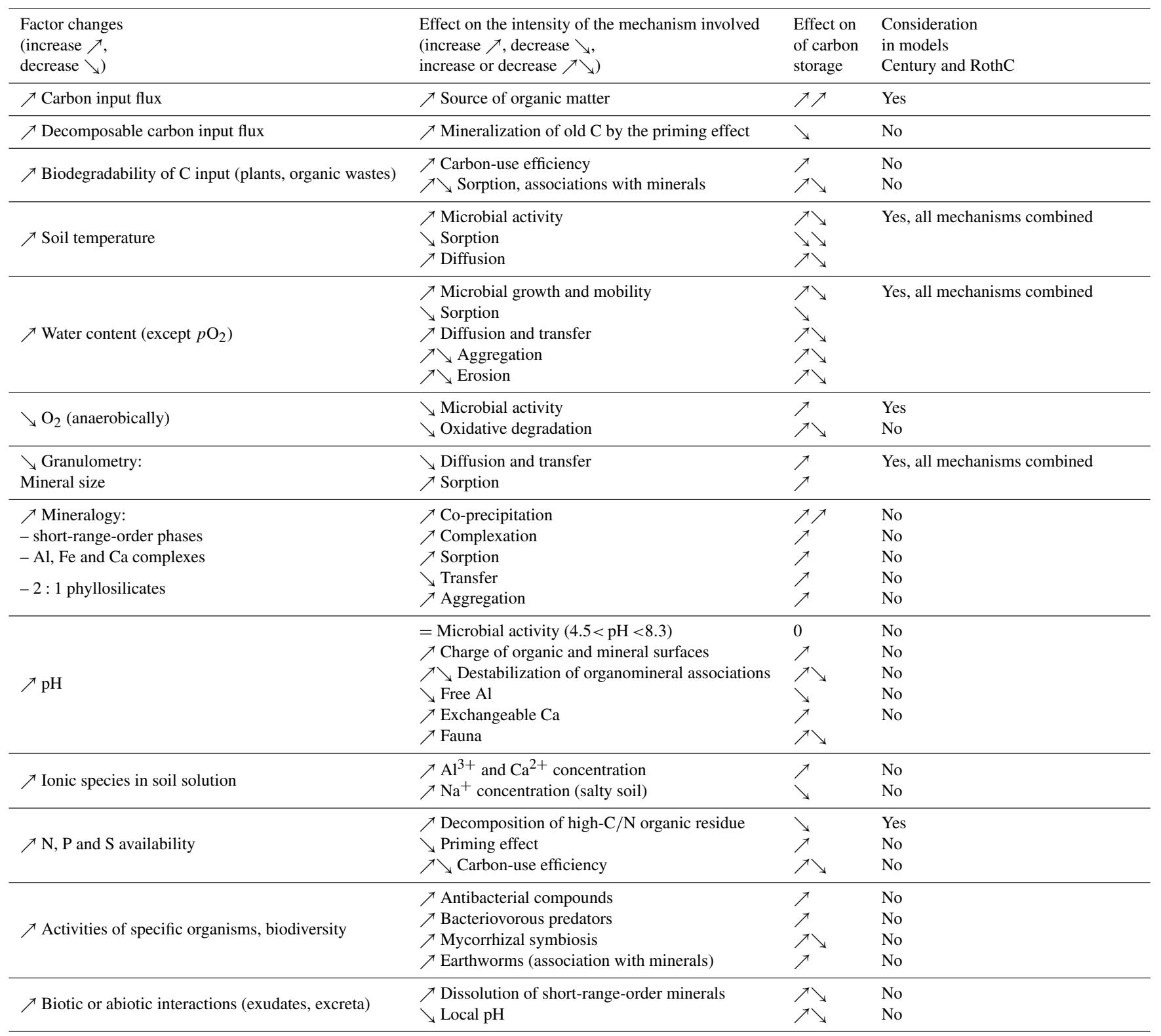

Particle size. Particle size is quite closely correlated with carbon stocks. The $<2 \mu \mathrm{m}$ fraction content can lead to twofold carbon stock variation. Fine granulometric fractions are often described as stable $\mathrm{C}$, with turnover times longer than the average values in soil (Balesdent, 1998). Metaanalyses have shown that the $<2 \mu \mathrm{m}$ fraction contains between $0 \%$ and $50 \%$ of the $\mathrm{C}$ stocks in national soil $\mathrm{C}$ inventories (Hassink, 1997) (see Sect. 2.4.1).

Mineralogy. Mineralogy is a major determinant of OM stabilization but is still poorly quantified and is combined with the nature of the ions available in solution (Rasmussen et al.,
2018). Mineral phases interacting with SOM (particularly poorly crystalline minerals) are not always stable (BasileDoelsch et al., 2015) and can be modified by land use, plants, pH and amendments (Collignon et al., 2011).

Soil $\mathrm{pH}$ and ions in the soil solution. The soil $\mathrm{pH}$ determined by conventional measurements is an average value that does not reflect the spatial heterogeneity of $\mathrm{pH}$ at the microto nanoscale. The $\mathrm{pH}$ has a greater effect on the soil physicochemistry than on the microbial physiology. The presence of calcium or magnesium ions in solution (dominant at $\mathrm{pH}>5$ ) and of active limestone tends to insolubilize OM and ad- 
sorb it by electrostatic interactions, e.g., via $\mathrm{Ca}^{2+}$ bridges (Sect. 2.4.1), thus reducing its biodegradation (Rowley et al., 2018). Aluminum has an equivalent role but in acidic $(<4.5)$ and aluminous soil (Rasmussen et al., 2018; Heckman et al., 2018). Conversely, biodegradation rates are high in salty soil where $\mathrm{Na}^{+}$predominates in the exchange complex (Qadir and Schubert, 2002). The action of $\mathrm{K}^{+}$has not been assessed. The soil $\mathrm{pH}$ also seems to control the phylogenetic diversity of microbes (Shen et al., 2013).

The availability and abundance of $N, P$ and $S$. These elements have various and complex effects. Organisms require specific ratios of $\mathrm{C}, \mathrm{N}, \mathrm{S}$ and $\mathrm{P}$ (i.e., stoichiometry) to survive and function optimally. For example, degradation of ligno-cellulosic debris (low nitrogen) is temporarily delayed in the absence of mineral nitrogen. Many other $\mathrm{C}, \mathrm{N}$ and $\mathrm{P}$ stoichiometry effects are involved in priming, biotic interactions or carbon-use efficiency (CUE) (Manzoni et al., 2012). $C: N: P$ ratios ranging from $72: 6: 1$ (observed in topsoils) to $32: 5: 1$ (observed in pastures) have been reported (Bertrand et al., 2019). Soil vertical stratification of $\mathrm{C}: \mathrm{N}: \mathrm{P}$ may, however, be important, and impacts on the soil stoichiometry have also been reported following land-use shifts. Regarding the additional amount of nutrients required to store the quantity of carbon targeted by the 4 per 1000 initiative, it has been suggested that $\mathrm{N}$ and $\mathrm{P}$ can be provided under current fertilization rates by reducing nutrient losses via improved management practices that include cover crops, fertilizer incorporation, etc. (Bertrand et al., 2019).

Biodiversity. Since bacteria are major actors in OM mineralization as well as in the production of stabilized compounds, the effects of nematode and protist predation of bacteria, as well as bacterial regulation by fungi, are uncertain (Barrios, 2007). The impact of pesticides on protists, nematodes and soil fungi could affect these regulations (Daam et al., 2011).

Biotic and/or abiotic interactions. The priming effect mechanism is involved in plant nutrient $(\mathrm{N}, \mathrm{P}, \mathrm{K})$ acquisition strategies. Plants release exudates and feed fungi through symbiotic associations (mycorrhiza) and bacteria from the rhizosphere that biodegrade OM (Fontaine et al., 2011) or even destabilize organomineral associations (Keiluweit et al., 2015) while releasing nitrogen compounds or phosphorus. Many other plant-microorganism interaction mechanisms (e.g., mycorrhizal type or polyphenol concentration) can also exert control over soil $\mathrm{C}$ through $\mathrm{N}$ competition (Northup et al., 1995; Averill et al., 2014), which allows the ecosystem to maintain a substantial reserve of elements and therefore a high degree of resilience.

Quantification of the effects of individually considered factors and mechanisms is still very incomplete and perhaps inappropriate, because (i) a single law controlling the turnover time of the different $\mathrm{C}$ pools is not expected when several mechanisms are involved (Table 2), and (ii) several factors interact (Cotrufo et al., 2015). Quantification procedures described in the scientific literature are rather confus- ing: many research groups estimate the weight of a factor by varying it and measuring mineralization flows, often in the short-term, despite the fact that these flows are not correlated with long-term carbon turnover times. For example, the effect of temperature has given rise to a number of divergent results (Davidson and Janssens, 2006; Sierra et al., 2015). Responses are also highly dependent on the soil type (von Luetzow et al., 2008).

In current operational models, only temperature, soil moisture, particle size and substrate $\mathrm{C} / \mathrm{N}$ are taken into account. They give quantitative estimates but fail to properly model dynamics. However, there are other overriding factors and priming effect modeling is emerging.

\section{Conclusions}

Soils have a decreasing $\mathrm{C}$ concentration gradient from the surface (a few percent by mass) to about $1 \mathrm{~m}$ deep (less than $1 \%$ ). Although previous research has mainly focused on the $0-30 \mathrm{~cm}$ horizon, it was recently shown that deep horizons $(>30 \mathrm{~cm})$ contribute up to $20 \%$ to the sequestration of new $\mathrm{C}$ over 20 years. OM observed in a soil at a given time results from a complex inheritance history linked to the functioning (and possible use) of a soil over several hundreds (or even thousands) of years.

Soil OM results from the biotransformation of inputs by plants (mainly belowground inputs). In soil, decomposer food webs and microorganisms are essential for the oxidative degradation and mineralization of organic molecules. The compounds that are not mineralized consist of microbederived (main contribution) and plant-derived small organic molecules and form the soil OM. In soil, transfer and association processes with minerals redistribute these organic molecules and/or more or less permanently shield them from the action of microorganisms through aggregation and organomineral interaction processes.

Long-term stabilization (this formulation is now preferred over the previous term humification) is therefore not driven by the same forces as short-term degradation rates. Plant, fauna, and microbial activity and biodiversity; mineralogy; water content; $p \mathrm{O}_{2}$; soil solution chemistry and $\mathrm{pH}$; and $\mathrm{N}$ and $\mathrm{P}$ availability, as well as soil temperature, thus control the mineralization-stabilization balance. The interdependencies of these factors, i.e., their time dependence (short- versus long-term response) and their relative importance with respect to the storage (or loss) of $\mathrm{C}$, are often not explained in detail, thus making it difficult to link $\mathrm{C}$ stock changes to specific processes and/or factors.

$\mathrm{C}$ stock predictions are conventionally modeled by linear OM decay dynamics approaches while only considering a few of these factors (temperature, water content, particle size, $\mathrm{pH}$ and sometimes $\mathrm{C}: \mathrm{N}$ interactions). Very few models account for nonlinear processes, such as priming, despite the increasing evidence of their key role in $\mathrm{C}$ dynamics. 
Greater insight into the mechanisms, their interdependencies, hierarchy and sensitivity to agricultural practices could generate future action levers for $\mathrm{C}$ sequestration in soil. Due to the timescale considered, the methods of choice should include retrospective studies or intercomparison of the findings of long-term experiments at specific sites.

Author contributions. IBD and JB contributed equally to the French chapter "Les mécanismes à l'origine du stockage/déstockage de C dans les sols" of the above-cited INRAE report. IBD drafted the English version. SP commented on the manuscript and led the INRAE report.

This paper is dedicated to Jérôme Balesdent, Research Director at INRAE, who died prematurely at the age of 63. Jérôme was a senior scientist at INRAE and one of the most renowned French soil scientists of his generation. Jérôme was a recognized pioneer in the use of stable $\mathrm{C}$ isotopes $\left({ }^{13} \mathrm{C}\right)$ for studying SOM dynamics in $\mathrm{C}_{3} / \mathrm{C}_{4}$ transitions. Here we would like to pay tribute to the great soil scientist and generous man he was. He will be greatly missed by the soil science community.

Competing interests. The authors declare that they have no conflict of interest.

Acknowledgements. This synthesis was written as part of the INRAE report "Storing carbon in French soils, what potential with regard to the objective 4 per 1000 and at what cost?" sponsored by the French Agence de l'Environnement et de la Maîtrise de l'Energie (ADEME) and the Ministère de l'Agriculture et de l'Alimentation (MAA) (Pellerin et al., 2019). We thank Claire Chenu, Bertrand Guenet and Denis Angers for their proofreading of the first French version and David Manley, a native English-speaking scientific translator, for the English version.

Review statement. This paper was edited by Sara Vicca and reviewed by two anonymous referees.

\section{References}

Allison, S. D., Wallenstein, M. D., and Bradford, M. A.: Soil-carbon response to warming dependent on microbial physiology, Nat. Geosci., 3, 336-340, https://doi.org/10.1038/NGEO846, 2010.

Amelung, W., Brodowski, S., Sandhage-Hofmann, A., and Bol, R.: Combining Biomarker with Stable Isotope Analyses for Assessing the Transformation and Turnover of Soil Organic Matter, Adv. Ag., 100, 155-250, 2008.

Amundson, R. and Biardeau, L.: Soil carbon sequestration is an elusive climate mitigation tool, P. Natl. Acad. Sci. USA, 115, 11652-11656, https://doi.org/10.1073/pnas.1815901115, 2018.

Amundson, R. and Biardeau, L.: Opinion: Soil carbon sequestration is an elusive climate mitigation tool, P. Natl. Acad. Sci. USA, 116, 13143-13143, https://doi.org/10.1073/pnas.1908917116, 2019.
Andriulo, A., Mary, B., and Guerif, J.: Modelling soil carbon dynamics with various cropping sequences on the rolling pampas, Agronomie, 19, 365-377, https://doi.org/10.1051/agro:19990504, 1999.

Averill, C., Turner, B. L., and Finzi, A. C.: Mycorrhiza-mediated competition between plants and decomposers drives soil carbon storage, Nature, 505, 543, https://doi.org/10.1038/nature12901, 2014.

Balesdent, J.: Les isotopes du carbone et la dynamique des matières organiques des sols, Cahiers Agr., 7, 201-206, 1998.

Balesdent, J., Chenu, C., and Balabane, M.: Relationship of soil organic matter dynamics to physical protection and tillage, Soil Till. Res., 53, 215-230, 2000.

Balesdent, J., Derrien, D., Fontaine, S., Kirman, S., Klumpp, K., Loiseau, P., Marol, C., Nguyen, C., Péan, M., Personi, E., and Robin, C.: Contribution de la rhizodéposition aux matières organiques du sol, quelques implications pour la modélisation de la dynamique du carbone, Etude et Gestion des Sols, 18, 201216, 2011.

Balesdent, J., Basile-Doelsch, I., Chadoeuf, J., Cornu, S., Fekiacova, Z., Fontaine, S., Guenet, B., and Hatte, C.: Turnover of deep organic carbon in cultivated soils: an estimate from a review of isotope data, Biotechnol. Agron. Soc., 21, 181-190, 2017.

Balesdent, J., Basile-Doelsch, I., Chadoeuf, J., Cornu, S., Derrien, D., Fekiacova, Z., and Hatte, C.: Atmosphere-soil carbon transfer as a function of soil depth, Nature, 559, 599-604, https://doi.org/10.1038/s41586-018-0328-3, 2018.

Banegas, N., Albanesi, A. S., Pedraza, R. O., and Dos Santos, D. A.: Non-linear dynamics of litter decomposition under different grazing management regimes, Plant Soil, 393, 47-56, https://doi.org/10.1007/s11104-015-2472-y, 2015.

Bardgett, R. D., Bowman, W. D., Kaufmann, R., and Schmidt, S. K.: A temporal approach to linking aboveground and belowground ecology, Trend. Ecol. Evol., 20, 634-641, https://doi.org/10.1016/j.tree.2005.08.005, 2005.

Barrios, E.: Soil biota, ecosystem services and land productivity, Ecol. Econom., 64, 269-285, https://doi.org/10.1016/j.ecolecon.2007.03.004, 2007.

Basile-Doelsch, I., Balesdent, J., and Rose, J.: Are Interactions between Organic Compounds and Nanoscale Weathering Minerals the Key Drivers of Carbon Storage in Soils?, Environ. Sci. Technol., 49, 3997-3998, 2015.

Baveye, P. C., Berthelin, J., Tessier, D., and Lemaire, G.: The "4 per 1000" initiative: A credibility issue for the soil science community?, Geoderma, 309, 118-123, https://doi.org/10.1016/j.geoderma.2017.05.005, 2018a.

Baveye, P. C., Berthelin, J., Tessier, D., and Lemaire, G.: The "4 per 1000" initiative: A credibility issue for the soil science community?, Geoderma, 309, 118-123, https://doi.org/10.1016/j.geoderma.2017.05.005, 2018b.

Baveye, P. C. and White, R. E.: The " $4 \mathrm{p} 1000$ " initiative: A new name should be adopted, Ambio, 49, 361-362, https://doi.org/10.1007/s13280-019-01188-9, 2020.

Bertrand, I., Viaud, V., Daufresne, T., Pellerin, S., and Recous, S.: Stoichiometry constraints challenge the potential of agroecological practices for the soil C storage. A review, Agron. Sustain. Dev., 39, 54 pp., https://doi.org/10.1007/s13593-019-0599$6,2019$. 
Besnard, E., Chenu, C., Balesdent, J., Puget, P., and Arrouays, D.: Fate of particulate organic matter in soil aggregates during cultivation, Eur. J. Soil Sci., 47, 495-503, https://doi.org/10.1111/j.1365-2389.1996.tb01849.x, 1996.

Bisigato, A. J., Laphitz, R. M. L., and Carrera, A. L.: Non-linear relationships between grazing pressure and conservation of soil resources in Patagonian Monte shrublands, J. Arid Environ., 72, 1464-1475, https://doi.org/10.1016/j.jaridenv.2008.02.016, 2008.

Blair, J. M., Falconer, R. E., Milne, A. C., Young, I. M., and Crawford, J. W.: ModelingThree-dimensional microstructure in heterogeneous media, Soil Sci. Soc. Am. J., 71, 1807-1812, https://doi.org/10.2136/ssaj2006.0113, 2007.

Blouin, M., Hodson, M. E., Delgado, E. A., Baker, G., Brussaard, L., Butt, K. R., Dai, J., Dendooven, L., Peres, G., Tondoh, J. E., Cluzeau, D., and Brun, J.-J.: A review of earthworm impact on soil function and ecosystem services, Eur. J. Soil Sci., 64, 161182, https://doi.org/10.1111/ejss.12025, 2013.

Bohlen, P. J., Pelletier, D. M., Groffman, P. M., Fahey, T. J., and Fisk, M. C.: Influence of earthworm invasion on redistribution and retention of soil carbon and nitrogen in northern temperate forests, Ecosystems, 7, 13-27, https://doi.org/10.1007/s10021003-0127-y, 2004.

Bol, R., Poirier, N., Balesdent, J., and Gleixner, G.: Molecular turnover time of soil organic matter in particle-size fractions of an arable soil, Rapid Commun. Mass Sp., 23, 2551-2558, 2009.

Bolinder, M. A., Angers, D. A., and Dubuc, J. P.: Estimating shoot to root ratios and annual carbon inputs in soils for cereal crops, Agr. Ecosys. Environ., 63, 61-66, https://doi.org/10.1016/S0167-8809(96)01121-8, 1997.

Bonkowski, M.: Protozoa and plant growth: the microbial loop in soil revisited, New Phytol., 162, 617-631, https://doi.org/10.1111/j.1469-8137.2004.01066.x, 2004.

Bonneville, S., Morgan, D. J., Schmalenberger, A., Bray, A., Brown, A., Banwart, S. A., and Benning, L. G.: Tree-mycorrhiza symbiosis accelerate mineral weathering: Evidences from nanometerscale elemental fluxes at the hypha-mineral interface, Geochim. Cosmochim. Ac., 75, 6988-7005, 2011.

Bosatta, E. and Agren, G. I.: The Power and Reactive Continuum Models as Particular Cases of the Q-Theory of OrganicMatter Dynamics, Geochim. Cosmochim. Ac., 59, 3833-3835, https://doi.org/10.1016/0016-7037(95)00287-A, 1995.

Brauman, A.: Effect of gut transit and mound deposit on soil organic matter transformations in the soil feeding termite: A review, Europ. J. Soil Biol., 36, 117-125, https://doi.org/10.1016/S11645563(00)01058-X, 2000.

Brown, G. G.: How Do Earthworms Affect Microfloral and Faunal Community Diversity, Plant Soil, 170, 209-231, https://doi.org/10.1007/BF02183068, 1995.

Buee, M., De Boer, W., Martin, F., van Overbeek, L., and Jurkevitch, E.: The rhizosphere zoo: An overview of plant-associated communities of microorganisms, including phages, bacteria, archaea, and fungi, and of some of their structuring factors, Plant Soil, 321, 189-212, https://doi.org/10.1007/s11104-009-9991-3, 2009

Burns, R. G., DeForest, J. L., Marxsen, J., Sinsabaugh, R. L., Stromberger, M. E., Wallenstein, M. D., Weintraub, M. N., and Zoppini, A.: Soil enzymes in a changing environment: Current knowledge and future directions, Soil Biol. Biochem., 58, 216234, https://doi.org/10.1016/j.soilbio.2012.11.009, 2013.

Calvet, R., Chenu, H., and Houot, S.: Les matières organiques des sols : rôles agronomiques et environnementaux, edited by: Agriproduction, Editions France Agricole, 347 pp., 2011.

Chappell, A., Baldock, J., and Sanderman, J.: The global significance of omitting soil erosion from soil organic carbon cycling schemes, Nat. Clim. Change, 6, 187-191, https://doi.org/10.1038/NCLIMATE2829, 2016.

Chen, F. L., Zheng, H., Zhang, K., Ouyang, Z. Y., Wu, Y. F., Shi, Q., and Li, H. L.: Non-linear impacts of Eucalyptus plantation stand age on soil microbial metabolic diversity, J. Soil. Sediment., 13, 887-894, https://doi.org/10.1007/s11368-013-0669-3, 2013.

Cheng, W., Parton, W. J., Gonzalez-Meler, M. A., Phillips, R., Asao, S., McNickle, G. G., Brzostek, E., and Jastrow, J. D.: Synthesis and modeling perspectives of rhizosphere priming, New Phytol., 201, 31-44, https://doi.org/10.1111/nph.12440, 2014.

Chenu, C. and Stotsky, G.: Interactions between microorganisms and soil partilces : an overview, in: Interactions between soil partilces and microorganisms edited by: Huang, P. M., Bollag, J. M., and Senesi, N., Wiley \& Sons, 2002.

Chevallier, T., Blanchart, E., Albrecht, A., and Feller, C.: The physical protection of soil organic carbon in aggregates: a mechanism of carbon storage in a Vertisol under pasture and market gardening (Martinique, West Indies), Agr. Ecosyst. Environ., 103, 375387, https://doi.org/10.1016/j.agee.2003.12.009, 2004.

Chevallier, T., Woignier, T., Toucet, J., and Blanchart, E.: Organic carbon stabilization in the fractal pore structure of Andosols, Geoderma, 159, 182-188, https://doi.org/10.1016/j.geoderma.2010.07.010, 2010.

Clemmensen, K. E., Bahr, A., Ovaskainen, O., Dahlberg, A., Ekblad, A., Wallander, H., Stenlid, J., Finlay, R. D., Wardle, D. A., and Lindahl, B. D.: Roots and Associated Fungi Drive Long-Term Carbon Sequestration in Boreal Forest, Science, 339, 1615-1618, https://doi.org/10.1126/science.1231923, 2013.

Coleman, K., Jenkinson, D. S., Crocker, G. J., Grace, P. R., Klir, J., Korschens, M., Poulton, P. R., and Richter, D. D.: Simulating trends in soil organic carbon in longterm experiments using RothC-26.3, Geoderma, 81, 29-44, https://doi.org/10.1016/s0016-7061(97)00079-7, 1997.

Collignon, C., Uroz, S., Turpault, M. P., and Frey-Klett, P.: Seasons differently impact the structure of mineral weathering bacterial communities in beech and spruce stands, Soil Biol. Biochem., 43, 2012-2022, 2011

Coq, S., Barthes, B. G., Oliver, R., Rabary, B., and Blanchart, E.: Earthworm activity affects soil aggregation and organic matter dynamics according to the quality and localization of crop residues - An experimental study (Madagascar), Soil Biol. Biochem., 39, 2119-2128, https://doi.org/10.1016/j.soilbio.2007.03.019, 2007.

Cotrufo, M. F., Wallenstein, M. D., Boot, C. M., Denef, K., and Paul, E.: The Microbial Efficiency-Matrix Stabilization (MEMS) framework integrates plant litter decomposition with soil organic matter stabilization: do labile plant inputs form stable soil organic matter?, Glob. Change Biol., 19, 988-995, https://doi.org/10.1111/gcb.12113, 2013.

Cotrufo, M. F., Soong, J. L., Horton, A. J., Campbell, E. E., Haddix, M. L., Wall, D. H., and Parton, A. J.: Formation of soil organic 
matter via biochemical and physical pathways of litter mass loss, Nat. Geosci., 8, 776, https://doi.org/10.1038/NGEO2520, 2015.

Curry, J. P. and Schmidt, O.: The feeding ecology of earthworms - A review, Pedobiologia, 50, 463-477, https://doi.org/10.1016/j.pedobi.2006.09.001, 2007.

Curtis, T. P. and Sloan, W. T.: Exploring microbial diversity - A vast below, Science, 309, 1331-1333, https://doi.org/10.1126/science.1118176, 2005.

Daam, M. A., Leitao, S., Cerejeira, M. J., and Sousa, J. P.: Comparing the sensitivity of soil invertebrates to pesticides with that of Eisenia fetida, Chemosphere, 85, 1040-1047, https://doi.org/10.1016/j.chemosphere.2011.07.032, 2011.

Davidson, E. A. and Janssens, I. A.: Temperature sensitivity of soil carbon decomposition and feedbacks to climate change, Nature, 440, 165-173, https://doi.org/10.1038/nature04514, 2006.

de Vries, W.: Soil carbon 4 per mille: a good initiative but let's manage not only the soil but also the expectations, Geoderma, 309, 111-112, https://doi.org/10.1016/j.geoderma.2017.05.023, 2018.

Dequiedt, S., Saby, N. P. A., Lelievre, M., Jolivet, C., Thioulouse, J., Toutain, B., Arrouays, D., Bispo, A., Lemanceau, P., and Ranjard, L.: Biogeographical patterns of soil molecular microbial biomass as influenced by soil characteristics and management, Glob. Ecol. Biogeogr.y, 20, 641-652, https://doi.org/10.1111/j.1466-8238.2010.00628.x, 2011.

Derrien, D., Marol, C., Balabane, M., and Balesdent, J.: The turnover of carbohydrate carbon in a cultivated soil estimated by ${ }^{13} \mathrm{C}$ natural abundances, Eur. J. Soil Sci., 57, 547-557, https://doi.org/10.1111/j.1365-2389.2006.00811.x, 2006.

Dignac, M.-F., Bahri, H., Rumpel, C., Rasse, D. P., Bardoux, G., Balesdent, J., Girardin, C., Chenu, C., and Mariotti, A.: Carbon13 natural abundance as a tool to study the dynamics of lignin monomers in soil: an appraisal at the Closeaux experimental field (France), Geoderma, 128, 3-17, 2005.

Dignac, M. F., Derrien, D., Barre, P., Barot, S., Cecillon, L., Chenu, C., Chevallier, T., Freschet, G. T., Garnier, P., Guenet, B., Hedde, M., Klumpp, K., Lashermes, G., Maron, P. A., Nunan, N., Roumet, C., and Basile-Doelsch, I.: Increasing soil carbon storage: mechanisms, effects of agricultural practices and proxies. A review, Agr. Sustain. Dev., 37, 27 pp., https://doi.org/10.1007/s13593-017-0421-2, 2017.

Doetterl, S., Berhe, A. A., Nadeu, E., Wang, Z. G., Sommer, M., and Fiener, P.: Erosion, deposition and soil carbon: A review of process-level controls, experimental tools and models to address C cycling in dynamic landscapes, Earth-Sci. Rev., 154, 102-122, https://doi.org/10.1016/j.earscirev.2015.12.005, 2016.

Don, A., Steinberg, B., Schoening, I., Pritsch, K., Joschko, M., Gleixner, G., and Schulze, E. D.: Organic carbon sequestration in earthworm burrows, Soil Biol. Biochem., 40, 1803-1812, https://doi.org/10.1016/j.soilbio.2008.03.003, 2008.

Don, A., Roedenbeck, C., and Gleixner, G.: Unexpected control of soil carbon turnover by soil carbon concentration, Environ. Chem. Lett., 11, 407-413, https://doi.org/10.1007/s10311-0130433-3, 2013.

Dungait, J. A. J., Hopkins, D. W., Gregory, A. S., and Whitmore, A. P.: Soil organic matter turnover is governed by accessibility not recalcitrance, Glob. Change Biol., 18, 1781-1796, https://doi.org/10.1111/j.1365-2486.2012.02665.x, 2012.
Elzein, A. and Balesdent, J.: Mechanistic Simulation of Vertical-Distribution of Carbon Concentrations and Residence Times in Soils, Soil Sci. Soc. Am. J., 59, 1328-1335, https://doi.org/10.2136/sssaj1995.03615995005900050019x, 1995.

Eriksson, E.: Compartment Models and Reservoir Theory, Annu. Rev. Ecol. Syst., 2, 67-84, https://doi.org/10.1146/annurev.es.02.110171.000435, 1971.

Eusterhues, K., Wagner, F. E., Hausler, W., Hanzlik, M., Knicker, H., Totsche, K. U., Kogel-Knabner, I., and Schwertmann, U.: Characterization of Ferrihydrite-Soil Organic Matter Coprecipitates by X-ray Diffraction and Mossbauer Spectroscopy, Environ. Sci. Technol., 42, 7891-7897, https://doi.org/10.1021/es800881w, 2008.

Falconer, R. E., Battaia, G., Schmidt, S., Baveye, P., Chenu, C., and Otten, W.: Microscale Heterogeneity Explains Experimental Variability and Non-Linearity in Soil Organic Matter Mineralisation, Plos One, 10, 12 pp., https://doi.org/10.1371/journal.pone.0123774, 2015.

Fan, J. L., McConkey, B., Janzen, H., Townley-Smith, L., and Wang, H.: Harvest index-yield relationship for estimating crop residue in cold continental climates, Field Crop. Res., 204, 153-157, https://doi.org/10.1016/j.fcr.2017.01.014, 2017.

Fontaine, S., Barot, S., Barre, P., Bdioui, N., Mary, B., and Rumpel, C.: Stability of organic carbon in deep soil layers controlled by fresh carbon supply, Nature, 450, 277-280, https://doi.org/10.1038/nature06275, 2007.

Fontaine, S., Henault, C., Aamor, A., Bdioui, N., Bloor, J. M. G., Maire, V., Mary, B., Revaillot, S., and Maron, P. A.: Fungi mediate long term sequestration of carbon and nitrogen in soil through their priming effect, Soil Biol. Biochem., 43, 86-96, https://doi.org/10.1016/j.soilbio.2010.09.017, 2011.

Frazão, J., de Goede, R. G. M., Capowiez, Y., and Pulleman, M. M.: Soil structure formation and organic matter distribution as affected by earthworm species interactions and crop residue placement, Geoderma, 338, 453-463, 2019.

Gans, J., Wolinsky, M., and Dunbar, J.: Computational improvements reveal great bacterial diversity and high metal toxicity in soil, Science, 309, 1387-1390, https://doi.org/10.1126/science.1112665, 2005.

Geyer, K. M., Kyker-Snowman, E., Grandy, A. S., and Frey, S. D.: Microbial carbon use efficiency: accounting for population, community, and ecosystem-scale controls over the fate of metabolized organic matter, Biogeochemistry, 127, 173-188, https://doi.org/10.1007/s10533-016-0191-y, 2016.

Gleixner, G., Czimczik, C. J., Kramer, C., Luehker, B., and Schmidt, M. W. I.: Plant compounds and their turnover and stabilization as soil organic matter, in: Global biogeochemical cycles in the climate system, edited by: Schulze, E. D., Heimann, M., Harrison, S., Holland, E. A., Llyod, J., Prentice, I. C., and Schimel, D. S., Academic Press, San Diego, 201-215, 2001.

Gmach, M. R., Cherubin, M. R., Kaiser, K., and Cerri, C. E. P.: Processes that influence dissolved organic matter in the soil: a review, Sci. Agr., 77, 10 pp., https://doi.org/10.1590/1678-992X2018-0164, 2020.

Golchin, A., Oades, J. M., Skjemstad, J. O., and Clarke, P.: Study of free and occluded particulate organic matter in soils by solidstate C-13 CP/MAS NMR-spectroscopy and scanning electron microscopy, Austr. J. Soil Res., 32, 285-309, 1994. 
Guiboileau, A., Sormani, R., Meyer, C., and Masclaux-Daubresse, C.: Senescence and death of plant organs: Nutrient recycling and developmental regulation, C. R. Biol., 333, 382-391, https://doi.org/10.1016/j.crvi.2010.01.016, 2010.

Guo, L. B. and Gifford, R. M.: Soil carbon stocks and land use change : a meta analysis, Glob. Change Biol., 8, 345-360, 2002.

Hassink, J.: The capacity of soils to preserve organic $\mathrm{C}$ and $\mathrm{N}$ by their association with clay and silt particles, Plant Soil, 191, 7787, https://doi.org/10.1023/A:1004213929699, 1997.

Hättenschwiler, S., Barantal, S., Ganault, P., Gillespie, L., and Coq, S.: Quels enjeux sont associés à la biodiversité des sols?, Innov. Agr., 69, 1-14, 2018.

Heckman, K., Lawrence, C. R., and Harden, J. W.: A sequential selective dissolution method to quantify storage and stability of organic carbon associated with $\mathrm{Al}$ and $\mathrm{Fe}$ hydroxide phases, Geoderma, 312, 24-35, https://doi.org/10.1016/j.geoderma.2017.09.043, 2018.

Hénin, S. and Dupuis, M.: Essai de bilan de la matiére organique du sol, Ann. Agron., 11, 17-29, 1945.

Hiederer, R. and Köchy, M.: Global Soil Organic Carbon Estimates and the Harmonized World Soil Database, EUR 25225 EN, Publications Office of the European Union, 79 pp., 2011.

Horrigue, W., Dequiedt, S., Prevost-Boure, N. C., Jolivet, C., Saby, N. P. A., Arrouays, D., Bispo, A., Maron, P. A., and Ranjard, L.: Predictive model of soil molecular microbial biomass, Ecol. Indic., 64, 203-211, https://doi.org/10.1016/j.ecolind.2015.12.004, 2016.

IPCC: Climate Change 2013: The Physical Science Basis. Contribution of Working Group I to the Fifth Assessment Report of the Intergovernmental Panel on Climate Change, Cambridge University Press, , Cambridge, United Kingdom and New York, NY, USA,, 1535 pp., 2013.

Jagercikova, M., Evrard, O., Balesdent, J., Lefèvre, I., and Cornu, S.: Modeling the migration of fallout radionuclides to quantify the contemporary transfer of fine particles in Luvisol profiles under different land uses and farming practices, Soil Till. Res., 140, 82-97, 2014.

Jagercikova, M., Cornu, S., Le Bas, C., and Evrard, O.: Vertical distributions of Cs-137 in soils: a meta-analysis, J. Soil. Sed., 15, 81-95, https://doi.org/10.1007/s11368-014-0982-5, 2015.

Jenkinson, D. S. and Rayner, J. H.: The turnover of soil organic matter in some of the Rothamsted classical experiments, Soil Sci., 123, 298-305, 1977.

Jobbagy, E. G. and Jackson, R. B.: The Vertical Distribution of Soil Organic Carbon and Its Relation to Climate and Vegetation, Ecol. Appl., 10, 423-436, https://doi.org/10.2307/2641104, 2000.

Jones, D. L., Nguyen, C., and Finlay, R. D.: Carbon flow in the rhizosphere: carbon trading at the soil-root interface, Plant Soil, 321, 5-33, https://doi.org/10.1007/s11104-009-9925-0, 2009.

Juarez, S., Nunan, N., Duday, A.-C., Pouteau, V., Schmidt, S., Hapca, S., Falconer, R., Otten, W., and Chenu, C.: Effects of different soil structures on the decomposition of native and added organic carbon, Europ. J. Soil Biol., 58, 81-90, https://doi.org/10.1016/j.ejsobi.2013.06.005, 2013.

Kallenbach, C. M., Frey, S. D., and Grandy, A. S.: Direct evidence for microbial-derived soil organic matter formation and its ecophysiological controls, Nat. Commun., 7, 10 pp., https://doi.org/10.1038/ncomms13630, 2016.
Katterer, T., Bolinder, M. A., Andren, O., Kirchmann, H., and Menichetti, L.: Roots contribute more to refractory soil organic matter than above-ground crop residues, as revealed by a longterm field experiment, Agr. Ecosyst. Environ., 141, 184-192, https://doi.org/10.1016/j.agee.2011.02.029, 2011.

Keiluweit, M., Bougoure, J. J., Nico, P. S., Pett-Ridge, J., Weber, P. K., and Kleber, M.: Mineral protection of soil carbon counteracted by root exudates, Nat. Clim. Change, 5, 588-595, https://doi.org/10.1038/nclimate2580, 2015.

Keiluweit, M., Wanzek, T., Kleber, M., Nico, P., and Fendorf, S.: Anaerobic microsites have an unaccounted role in soil carbon stabilization, Nat. Commun., 8, 588-595, https://doi.org/10.1038/s41467-017-01406-6, 2017.

Kelleher, B. P. and Simpson, A. J.: Humic substances in soils: Are they really chemically distinct?, Environ. Sci. Technol., 40, 4605-4611, https://doi.org/10.1021/es0608085, 2006.

Kéraval, B., Lehours, A. C., Colombet, J., Amblard, C., A1varez, G., and Fontaine, S.: Soil carbon dioxide emissions controlled by an extracellular oxidative metabolism identifiable by its isotope signature, Biogeosciences, 13, 6353-6362, https://doi.org/10.5194/bg-13-6353-2016, 2016.

Killham, K., Amato, M., and Ladd, J. N.: Effect of Substrate Location in Soil and Soil Pore-Water Regime on Carbon Turnover, Soil Biol. Biochem., 25, 57-62, https://doi.org/10.1016/00380717(93)90241-3, 1993.

Kleber, M., Sollins, P., and Sutton, R.: A conceptual model of organo-mineral interactions in soils: self-assembly of organic molecular fragments into zonal structures on mineral surfaces, Biogeochemistry, 85, 9-24, https://doi.org/10.1007/s10533-0079103-5, 2007.

Kleber, M., Eusterhues, K., Keiluweit, M., Mikutta, C., Mikutta, R., and Nico, P. S.: Chapter One - Mineral-Organic Associations: Formation, Properties, and Relevance in Soil Environments, in: Advances in Agronomy, edited by: Donald, L. S., Academic Press, 1-140, 2015.

Klupfel, L., Piepenbrock, A., Kappler, A., and Sander, M.: Humic substances as fully regenerable electron acceptors in recurrently anoxic environments, Nat. Geosci., 7, 195-200, https://doi.org/10.1038/NGEO2084, 2014.

Kogel-Knabner, I.: The macromolecular organic composition of plant and microbial residues as inputs to soil organic matter: Fourteen years on, Soil Biol. Biochem., 105, A3-A8, https://doi.org/10.1016/j.soilbio.2016.08.011, 2017.

Kögel-Knabner, I., Guggenberger, G., Kleber, M., Kandeler, E., Kalbitz, K., Scheu, S., Eusterhues, K., and Leinweber, P. Organo-mineral associations in temperate soils: Integrating biology, mineralogy, and organic matter chemistry, J. Plant Nutr. Soil Sci., 171, 61-82, https://doi.org/10.1002/jpln.200700048, 2008.

Kuzyakov, Y., Friedel, J. K., and Stahr, K.: Review of mechanisms and quantification of priming effects, Soil Biol. Biochem., 32, 1485-1498, https://doi.org/10.1016/S0038-0717(00)000845,2000

Lal, R.: Soil degradation by erosion, Land Degrad. Dev., 12, 519_ 539, https://doi.org/10.1002/ldr.472, 2001.

Larney, F. J. and Angers, D. A.: The role of organic amendments in soil reclamation: A review, Can. J. Soil Sci., 92, 19-38, https://doi.org/10.4141/CJSS2010-064, 2012.

Lashermes, G., Gainvors-Claisse, A., Recous, S., and Bertrand, I.: Enzymatic Strategies and Carbon Use Effi- 
ciency of a Litter-Decomposing Fungus Grown on Maize Leaves, Stems, and Roots, Front. Microbiol., 7, 14 pp., https://doi.org/10.3389/fmicb.2016.01315, 2016.

Lavallee, J. M., Conant, R. T., Paul, E. A., and Cotrufo, M. F.: Incorporation of shoot versus root-derived $\mathrm{C}-13$ and $\mathrm{N}-15$ into mineral-associated organic matter fractions: results of a soil slurry incubation with dual-labelled plant material, Biogeochemistry, 137, 379-393, https://doi.org/10.1007/s10533-018-0428-z, 2018.

Lavelle, P., Spain, A., Blouin, M., Brown, G., Decaëns, T., Grimaldi, M., Jiménez, J. J., McKey, D., Mathieu, J., Velasquez, E., and Zangerlé, A.: Ecosystem Engineers in a Self-organized Soil: A Review of Concepts and Future Research Questions, Soil Sci., 181, 91-109, https://doi.org/10.1097/ss.0000000000000155, 2016.

Lehmann, J., Rillig, M. C., Thies, J., Masiello, C. A., Hockaday, W. C., and Crowley, D.: Biochar effects on soil biota - A review, Soil Biol. Biochem., 43, 1812-1836, https://doi.org/10.1016/j.soilbio.2011.04.022, 2011.

Lehmann, J. and Kleber, M.: The contentious nature of soil organic matter, Nature, 528, 60-68, https://doi.org/10.1038/nature16069, 2015.

Lennon, J. T. and Jones, S. E.: Microbial seed banks: the ecological and evolutionary implications of dormancy, Nat. Rev. Microbiol., 9, 119-130, https://doi.org/10.1038/nrmicro2504, 2011.

Levard, C., Doelsch, E., Basile-Doelsch, I., Abidin, Z., Miche, H., Masion, A., Rose, J., Borschneck, D., and Bottero, J. Y.: Structure and distribution of allophanes, imogolite and protoimogolite in volcanic soils, Geoderma, 183/184, 100-108, 2012.

Liyanage, A., Grace, P. R., Scheer, C., de Rosa, D., Ranwala, S., and Rowlings, D. W.: Carbon limits non-linear response of nitrous oxide $\left(\mathrm{N}_{2} \mathrm{O}\right)$ to increasing $\mathrm{N}$ inputs in a highly-weathered tropical soil in Sri Lanka, Agr. Ecosyst. Environ., 292, 10 pp., https://doi.org/10.1016/j.agee.2019.106808, 2020.

Loisel, J., Connors, J. P. C., Hugelius, G., Harden, J. W., and Morgan, C. L.: Soils can helpmitigate $\mathrm{CO}_{2}$ emissions, despite the challenges, P. Natl. Acad. Sci. USA, 116, 10211-10212, https://doi.org/10.1073/pnas.1900444116, 2019.

Manzoni, S., Taylor, P., Richter, A., Porporato, A., and Agren, G. I.: Environmental and stoichiometric controls on microbial carbon-use efficiency in soils, New Phytol., 196, 79-91, https://doi.org/10.1111/j.1469-8137.2012.04225.x, 2012.

Martin, A., Mariotti, A., Balesdent, J., Lavelle, P., and Vuattoux, R.: Estimate of Organic-Matter Turnover Rate in a Savanna Soil by C-13 Natural Abundance Measurements, Soil Biol. Biochem., 22, 517-523, https://doi.org/10.1016/00380717(90)90188-6, 1990.

Mathieu, J., Hatté, C., Balesdent, J., and Parent, E.: Deep soil carbon dynamics are driven more by soil type than by climate: a worldwide meta-analysis of radiocarbon profiles, Glob. Change Biol., 21, 4278-4290, 2015.

McNicol, G. and Silver, W. L.: Non-linear response of carbon dioxide and methane emissions to oxygen availability in a drained histosol, Biogeochemistry, 123, 299-306, https://doi.org/10.1007/s10533-015-0075-6, 2015.

Mikutta, R., Kleber, M., Torn, M., and Jahn, R.: Stabilization of Soil Organic Matter: Association with Minerals or Chemical Recalcitrance?, Biogeochemistry, 77, 25-56, 2006.
Miltner, A., Bombach, P., Schmidt-Brucken, B., and Kastner, M.: SOM genesis: microbial biomass as a significant source, Biogeochemistry, 111, 41-55, 2012.

Minasny, B., Malone, B. P., McBratney, A. B., Angers, D. A., Arrouays, D., Chambers, A., Chaplot, V., Chen, Z. S., Cheng, K., Das, B. S., Field, D. J., Gimona, A., Hedley, C. B., Hong, S. Y., Mandal, B., Marchant, B. P., Martin, M., McConkey, B. G., Mulder, V. L., O'Rourke, S., Richer-deForges, A. C., Odeh, I., Padarian, J., Paustian, K., Pan, G. X., Poggio, L., Savin, I., Stolbovoy, V., Stockmann, U., Sulaeman, Y., Tsui, C. C., Vagen, T. G., van Wesemael, B., and Winowiecki, L.: Soil carbon 4 per mille, Geoderma, 292, 59-86, https://doi.org/10.1016/j.geoderma.2017.01.002, 2017.

Minasny, B., Arrouays, D., McBratney, A. B., Angers, D. A., Chambers, A., Chaplot, V., Chen, Z. S., Cheng, K., Das, B. S., Field, D. J., Gimona, A., Hedley, C., Hong, S. Y., Mandal, B., Malone, B. P., Marchant, B. P., Martin, M., McConkey, B. G., Mulder, V. L., O’Rourke, S., Richer-de-Forges, A. C., Odeh, I., Padarian, J., Paustian, K., Pan, G. X., Poggio, L., Savin, I., Stolbovoy, V., Stockmann, U., Sulaeman, Y., Tsui, C. C., Vagen, T. G., van Wesemael, B., and Winowiecki, L.: Rejoinder to Comments on Minasny et al., 2017 Soil carbon 4 per mille Geoderma 292, 59-86, Geoderma, 309, 124-129, https://doi.org/10.1016/j.geoderma.2017.05.026, 2018.

Monga, O., Bousso, M., Garnier, P., and Pot, V.: 3D geometric structures and biological activity: Application to microbial soil organic matter decomposition in pore space, Ecol. Model., 216, 291-302, https://doi.org/10.1016/j.ecolmodel.2008.04.015, 2008.

Monga, O., Garnier, P., Pot, V., Coucheney, E., Nunan, N., Otten, W., and Chenu, C.: Simulating microbial degradation of organic matter in a simple porous system using the 3-D diffusion-based model MOSAIC, Biogeosciences, 11, 22012209, https://doi.org/10.5194/bg-11-2201-2014, 2014.

Montagnani, L., Badraghi, A., Speak, A. F., Wellstein, C., Borruso, L., Zerbe, S., and Zanotelli, D.: Evidence for a nonlinear carbon accumulation pattern along an Alpine glacier retreat chronosequence in Northern Italy, Peerj, 7, 27 pp., https://doi.org/10.7717/peerj.7703, 2019.

Montgomery, D. R.: Soil erosion and agricultural sustainability, P. Natl. Acad. Sci. USA, 104, 13268-13272, https://doi.org/10.1073/pnas.0611508104, 2007.

Mooshammer, M., Wanek, W., Hammerle, I., Fuchslueger, L., Hofhansl, F., Knoltsch, A., Schnecker, J., Takriti, M., Watzka, M., Wild, B., Keiblinger, K. M., Zechmeister-Boltenstern, S., and Richter, A.: Adjustment of microbial nitrogen use efficiency to carbon: nitrogen imbalances regulates soil nitrogen cycling, Nat. Commun., 5, 7 pp., https://doi.org/10.1038/ncomms4694, 2014.

Mulder, V. L., Lacoste, M., Martin, M. P., Richer-de-Forges, A., and Arrouays, D.: Understanding large-extent controls of soil organic carbon storage in relation to soil depth and soillandscape systems, Global Biogeochem. Cy., 29, 1210-1229, https://doi.org/10.1002/2015GB005178, 2015.

Mulder, V. L., Lacoste, M., Richer-de-Forges, A. C., Martin, M. P., and Arrouays, D.: National versus global modelling the 3D distribution of soil organic carbon in mainland France, Geoderma, 263, 16-34, https://doi.org/10.1016/j.geoderma.2015.08.035, 2016. 
Nguyen, C.: Rhizodeposition of organic C by plants: mechanisms and controls, Agronomie, 23, 375-396, https://doi.org/10.1051/agro:2003011, 2003.

Northup, R. R., Yu, Z. S., Dahlgren, R. A., and Vogt, K. A.: Polyphenol Control of Nitrogen Release from Pine Litter, Nature, 377, 227-229, https://doi.org/10.1038/377227a0, 1995.

Nunan, N., Schmidt, H., and Raynaud, X.: The ecology of heterogeneity: soil bacterial communities and $\mathrm{C}$ dynamics, Philos. $\mathrm{T}$. R. Soc. B, 375, 11 pp., https://doi.org/10.1098/rstb.2019.0249, 2020

Oades, J. M.: The Retention of Organic-Matter in Soils, Biogeochemistry, 5, 35-70, https://doi.org/10.1007/BF02180317, 1988.

Pajor, R., Falconer, R., Hapca, S., and Otten, W.: Modelling and quantifying the effect of heterogeneity in soil physical conditions on fungal growth, Biogeosciences, 7, 3731-3740, https://doi.org/10.5194/bg-7-3731-2010, 2010.

Parton, W. J., Schimel, D. S., Cole, C. V., and Ojima, D. S.: Analysis of factors controlling SOM levels in Great Plains grasslands Soil, Soil Sci. Soc. Am. J., 51, 1173-1779, 1987.

Parton, W. J. and Rasmussen, P. E.: Long-term effects of crop management in wheat-fallow, 2. Century model simulations, Soil Sci. Soc. Am. J., 58, 530-536, https://doi.org/10.2136/sssaj1994.03615995005800020040x, 1994.

Pellerin, S., Bamière, L., Launay, C., Martin, R., Schiavo, M., Angers, D., Augusto, L., Balesdent, J., Basile Doelsch, I., Bellassen, V., Cardinael, R., Cécillon, L., Ceschia, E., Chenu C., Constantin J., Daroussin, J., Delacote, P., Delame, N., Gastal, F., Gilbert D., Graux, A.-I., Guenet, B., Houot, S., Klumpp, K., Letort, E., Litrico I., Martin, M., Menasseri, S., Meziere, D., Morvan, T., Mosnier, C., Roger-Estrade, J., Saint-André, L., Sierra J., Therond, O., Viaud, V., Grateau R., Le Perchec S., Savini I., Rechauchère, O.: Stocker du carbone dans les sols français ; quel potentiel au regard de l'objectif 4 pour 1000 et à quel coût?, Research report summary, INRAE (France), 114 pp., 2019.

Pinheiro, M., Garnier, P., Beguet, J., Laurent, F. M., and Gonod, L. V.: The millimetre-scale distribution of 2,4-D and its degraders drives the fate of 2,4-D at the soil core scale, Soil Biol. Biochem., 88, 90-100, https://doi.org/10.1016/j.soilbio.2015.05.008, 2015.

Plante, A. F., Conant, R. T., Paul, E. A., Paustian, K., and Six, J.: Acid hydrolysis of easily dispersed and microaggregate-derived silt- and clay-sized fractions to isolate resistant soil organic matter, Eur. J. Soil Sci., 57, 456-467, https://doi.org/10.1111/j.13652389.2006.00792.x, 2006.

Poeplau, C. and Katterer, T.: Is soil texture a major controlling factor of root:shoot ratio in cereals?, Eur. J. Soil Sci., 68, 964-970, https://doi.org/10.1111/ejss.12466, 2017.

Qadir, M. and Schubert, S.: Degradation processes and nutrient constraints in sodic soils, Land Degrad. Dev., 13, 275-294, https://doi.org/10.1002/ldr.504, 2002.

Rasmussen, C., Heckman, K., Wieder, W. R., Keiluweit, M., Lawrence, C. R., Berhe, A. A., Blankinship, J. C., Crow, S. E., Druhan, J. L., Pries, C. E. H., Marin-Spiotta, E., Plante, A. F., Schadel, C., Schimel, J. P., Sierra, C. A., Thompson, A., and Wagai, R.: Beyond clay: towards an improved set of variables for predicting soil organic matter content, Biogeochemistry, 137, 297-306, https://doi.org/10.1007/s10533-018-0424-3, 2018.
Rasse, D., Rumpel, C., and Dignac, M.-F.: Is soil carbon mostly root carbon? Mechanisms for a specific stabilisation, Plant Soil, 269, 341-356, https://doi.org/10.1007/s11104-004-0907-y, 2005.

Remusat, L., Hatton, P. J., Nico, P. S., Zeller, B., Kleber, M., and Derrien, D.: NanoSIMS Study of Organic Matter Associated with Soil Aggregates: Advantages, Limitations, and Combination with STXM, Environ. Sci. Technol., 46, 3943-3949, https://doi.org/10.1021/es203745k, 2012.

Resat, H., Bailey, V., McCue, L. A., and Konopka, A.: Modeling Microbial Dynamics in Heterogeneous Environments: Growth on Soil Carbon Sources, Microb. Ecol., 63, 883-897, https://doi.org/10.1007/s00248-011-9965-x, 2012.

Rochette, P. and Angers, D. A.: Soil surface carbon dioxide fluxes induced by spring, summer, and fall moldboard plowing in a sandy loam, Soil Sci. Soc. Am. J., 63, 621-628, https://doi.org/10.2136/sssaj1999.03615995006300030027x, 1999.

Rovira, A. D. and Greacen, E. L.: The effect of aggregate disruption on the activity of microorganisms in the soil, Austr. J. Agr. Res., 8, 659-673, 1957.

Rowley, M. C., Grand, S., and Verrecchia, É. P.: Calcium-mediated stabilisation of soil organic carbon, Biogeochemistry, 137, 27 49, https://doi.org/10.1007/s10533-017-0410-1, 2018.

Ruamps, L. S., Nunan, N., Pouteau, V., Leloup, J., Raynaud, X., Roy, V., and Chenu, C.: Regulation of soil organic C mineralisation at the pore scale, Fems Microbiol. Ecol., 86, 26-35, https://doi.org/10.1111/1574-6941.12078, 2013.

Rumpel, C.: Soils linked to climate change, Nature, 572, 442-443, https://doi.org/10.1038/d41586-019-02450-6, 2019.

Sallih, Z. and Bottner, P.: Effect of Wheat (Triticum-Aestivum) Roots on Mineralization Rates of Soil Organic-Matter, Biol. Fertil. Soil., 7, 67-70, 1988.

Schimel, J.: SOIL CARBON Microbes and global carbon, Nat. Clim. Change, 3, 867-868, 2013.

Schmidt, M. W. I., Torn, M. S., Abiven, S., Dittmar, T., Guggenberger, G., Janssens, I. A., Kleber, M., Kogel-Knabner, I., Lehmann, J., Manning, D. A. C., Nannipieri, P., Rasse, D. P., Weiner, S., and Trumbore, S. E.: Persistence of soil organic matter as an ecosystem property, Nature, 478, 49-56, 2011.

Senesi, N. and Plaza, C.: Role of humification processes in recycling organic wastes of various nature and sources as soil amendments, Clean-Soil Air Water, 35, 26-41, https://doi.org/10.1002/clen.200600018, 2007.

Shan, J., Brune, A., and Ji, R.: Selective digestion of the proteinaceous component of humic substances by the geophagous earthworms Metaphire guillelmi and Amynthas corrugatus, Soil Biol. Biochem., 42, 1455-1462, https://doi.org/10.1016/j.soilbio.2010.05.008, 2010.

Shen, C. C., Xiong, J. B., Zhang, H. Y., Feng, Y. Z., Lin, X. G., Li, X. Y., Liang, W. J., and Chu, H. Y.: Soil pH drives the spatial distribution of bacterial communities along elevation on Changbai Mountain, Soil Biol. Biochem., 57, 204-211, https://doi.org/10.1016/j.soilbio.2012.07.013, 2013.

Sierra, C. A., Trumbore, S. E., Davidson, E. A., Vicca, S., and Janssens, I.: Sensitivity of decomposition rates of soil organic matter with respect to simultaneous changes in temperature and moisture, J. Adv. Model. Earth Syst., 7, 335-356, https://doi.org/10.1002/2014MS000358, 2015. 
Sierra, C. A., Müller, M., Metzler, H., Manzoni, S., and Trumbore, S. E.: The muddle of ages, turnover, transit, and residence times in the carbon cycle, Glob. Change Biol., 23, 1763-1773, https://doi.org/10.1111/gcb.13556, 2017.

Sinsabaugh, R. L., Manzoni, S., Moorhead, D. L., and Richter, A.: Carbon use efficiency of microbial communities: stoichiometry, methodology and modelling, Ecol. Lett., 16, 930-939, https://doi.org/10.1111/ele.12113, 2013.

Sinsabaugh, R. L., Belnap, J., Findlay, S. G., Shah, J. J. F., Hill, B. H., Kuehn, K. A., Kuske, C. R., Litvak, M. E., Martinez, N. G., Moorhead, D. L., and Warnock, D. D.: Extracellular enzyme kinetics scale with resource availability, Biogeochemistry, 121, 287-304, https://doi.org/10.1007/s10533-014-0030-y, 2014.

Sistla, S. A., Moore, J. C., Simpson, R. T., Gough, L., Shaver, G. R., and Schimel, J. P.: Long-term warming restructures Arctic tundra without changing net soil carbon storage, Nature, 497, 615, https://doi.org/10.1038/nature12129, 2013.

Six, J., Elliott, E. T., Paustian, K., and Doran, J. W.: Aggregation and Soil Organic Matter Accumulation in Cultivated and Native Grassland Soils, Soil Sci. Soc. Am. J., 62, 1367-1377 1998.

Six, J., Conant, E., Paul, E. A., and Paustian, K.: Stabilization mechanisms of soil organic matter : implications for C-saturation of soils, Plant Soil, 241, 155-176, 2002.

Stahl, C., Fontaine, S., Klumpp, K., Picon-Cochard, C., Grise, M. M., Dezecache, C., Ponchant, L., Freycon, V., Blanc, L., Bonal, D., Burban, B., Soussana, J. F., and Blanfort, V.: Continuous soil carbon storage of old permanent pastures in Amazonia, Glob. Change Biol., 23, 3382-3392, https://doi.org/10.1111/gcb.13573, 2017.

Stamati, F. E., Nikolaidis, N. P., Banwart, S., and Blum, W. E. H.: A coupled carbon, aggregation, and structure turnover (CAST) model for topsoils, Geoderma, 211, 51-64, https://doi.org/10.1016/j.geoderma.2013.06.014, 2013.

Sutton, R. and Sposito, G.: Molecular Structure in Soil Humic Substances: The New View, Environ. Sci. Technol., 39, 9009-9015, 2005.

Tamrat, W. Z., Rose, J., Grauby, O., Doelsch, E., Levard, C., Chaurand, P., and Basile-Doelsch, I.: Composition and molecular scale structure of nanophases formed by precipitation of biotite weathering products, Geochim. Cosmochim. Ac., 229, 53-64, 10.1016/j.gca.2018.03.012, 2018.

Tamrat, W. Z., Rose, J., Grauby, O., Doelsch, E., Levard, C., Chaurand, P., and Basile-Doelsch, I.: Soil organo-mineral associations formed by co-precipitation of $\mathrm{Fe}, \mathrm{Si}$ and $\mathrm{Al}$ in presence of organic ligands, Geochim. Cosmochim. Ac., 260, 15-28, https://doi.org/10.1016/j.gca.2019.05.043, 2019.

Terrat, S., Horrigue, W., Dequietd, S., Saby, N. P. A., Lelievre, M., Nowak, V., Tripied, J., Regnier, T., Jolivet, C., Arrouays, D., Wincker, P., Cruaud, C., Karimi, B., Bispo, A., Maron, P. A., Prevost-Boure, N. C., and Ranjard, L.: Mapping and predictive variations of soil bacterial richness across France, Plos One, 12, 19 pp., https://doi.org/10.1371/journal.pone.0186766, 2017.

Torn, M. S., Trumbore, S. E., Chadwick, O. A., Vistousek, P. M., and Hendricks, D. M.: Mineral control of soil organic carbon and turnover, Nature, London, 389, 170-173, 1997.

Torsvik, V. and Ovreas, L.: Microbial diversity and function in soil: from genes to ecosystems, Curr. Opin. Microbiol., 5, 240-245, https://doi.org/10.1016/S1369-5274(02)00324-7, 2002.
Trap, J., Bonkowski, M., Plassard, C., Villenave, C., and Blanchart, E.: Ecological importance of soil bacterivores for ecosystem functions, Plant Soil, 398, 1-24, https://doi.org/10.1007/s11104015-2671-6, 2016.

van Groenigen, J. W., van Kessel, C., Hungate, B. A., Oenema, O., Powlson, D. S., and van Groenigen, K. J.: Sequestering Soil Organic Carbon: A Nitrogen Dilemma, Environ. Sci. Technol., 51, 4738-4739, https://doi.org/10.1021/acs.est.7b01427, 2017.

VandenBygaart, A. J.: Comments on soil carbon 4 per mille by Minasny et al. 2017, Geoderma, 309, 113-114, https://doi.org/10.1016/j.geoderma.2017.05.024, 2018.

Vidal, A., Quenea, K., Alexis, M., and Derenne, S.: Molecular fate of root and shoot litter on incorporation and decomposition in earthworm casts, Organ. Geochem., 101, 1-10, https://doi.org/10.1016/j.orggeochem.2016.08.003, 2016.

Vogel, C., Mueller, C., Höschen, C., Buegger, F., Heister, K., Schulz, S., Schloter, M., and Kögel-Knabner, I.: Submicron structures provide preferential spots for carbon and nitrogen sequestration in soils, Nat. Commun., 5, 7 pp., https://doi.org/10.1038/ncomms3947, 2014.

Vogel, L. E., Makowski, D., Garnier, P., Vieublé-Gonod, L., Coquet, Y., Raynaud, X., Nunan, N., Chenu, C., Falconer, R., and Pot, V.: Modeling the effect of soil mesoand macropores topology on the biodegradation of a soluble carbon substrate, Adv. Water Resour., 83, 123-136, https://doi.org/10.1016/j.advwatres.2015.05.020, 2015.

von Luetzow, M., Kogel-Knabner, I., Ludwig, B., Matzner, E., Flessa, H., Ekschmitt, K., Guggenberger, G., Marschner, B., and Kalbitz, K.: Stabilization mechanisms of organic matter in four temperate soils: Development and application of a conceptual model, J. Plant Nutr. Soil Sci.-Z., 171, 111-124, 2008.

Wen, Y., Su, L. M., Qin, W. C., Fu, L., He, J., and Zhao, Y. H.: Linear and non-linear relationships between soil sorption and hydrophobicity: Model, validation and influencing factors, Chemosphere, 86, 634-640, https://doi.org/10.1016/j.chemosphere.2011.11.001, 2012.

West, T. O. and Six, J.: Considering the influence of sequestration duration and carbon saturation on estimates of soil carbon capacity, Climatic Change, 80, 25-41, https://doi.org/10.1007/s10584006-9173-8, 2007.

White, R. E., Davidson, B., Lam, S. K., and Chen, D. L.: A critique of the paper "Soil carbon 4 per mille" by Minasny et al. (2017), Geoderma, 309, 115-117, https://doi.org/10.1016/j.geoderma.2017.05.025, 2018.

Wiesmeier, M., Urbanski, L., Hobley, E., Lang, B., von Lützow, M., Marin-Spiotta, E., van Wesemael, B., Rabot, E., Ließ, M., Garcia-Franco, N., Wollschläger, U., Vogel, H.-J., and KögelKnabner, I.: Soil organic carbon storage as a key function of soils - A review of drivers and indicators at various scales, Geoderma, 333, 149-162, https://doi.org/10.1016/j.geoderma.2018.07.026, 2019.

Zangerle, A., Pando, A., and Lavelle, P.: Do earthworms and roots cooperate to build soil macroaggregates? A microcosm experiment, Geoderma, 167/168, 303-309, https://doi.org/10.1016/j.geoderma.2011.09.004, 2011.

Zimmerman, A. R., Chorover, J., Goyne, K. W., and Brantley, S. L.: Protection of Mesopore-Adsorbed Organic Matter from Enzymatic Degradation, Environ. Sci. Technol., 38, 4542-4548, https://doi.org/10.1021/es035340, 2004. 